\title{
12
}

\section{Asymmetrical Distinctions in Waanyi Kinship Terminology ${ }^{1}$}

\author{
Mary Laughren
}

\section{Introduction}

\section{Background}

Waanyi ${ }^{2}$ kinship terms map onto an 'Arandic' system with distinct encoding of the four logical combinations of maternal and paternal relations in the ascending harmonic ('grandparent') generation:

1 Without the generous collaboration of the late Mr Roy Seccin Kamarrangi, who valiantly attempted to teach me Waanyi between 2000 and 2005, this study would not have begun. I also acknowledge the assistance received from the late Mr Eric King Balyarrinyi and his companions at the Doomadgee nursing home. I am indebted to Gavan Breen, who shared his Waanyi field notes and insights with me, and to John Dymock, who gave me copies of his vast corpus of Waanyi vocabulary. Thank you to the two anonymous reviewers, whose input to the development of this chapter was substantial, and to Barry Alpher, who provided invaluable feedback on an earlier draft. Errors of fact or interpretation remain my responsibility. The research on Waanyi was supported by a number of small ARC grants through the University of Queensland and the Waanyi Nation Aboriginal Corporation.

2 Waanyi was traditionally spoken in land watered by the upper branches of the Nicholson River and its tributaries, which straddles the Queensland-Northern Territory border to the south of the Gulf of Carpentaria (see Tindale 1974; Trigger 1982). The most closely related language is Garrwa (Breen 2003; Mushin 2012), spoken to the immediate north of Waanyi. The Garrwa-Waanyi language block lies between the northern and southern branches of the Warluwarric language group (Blake $1988,1990)$ and is bordered on the east by the Tangkic language Yukulta, also called Ganggalida, (Keen 1983; Nancarrow et al. 2014), which Seccin referred to as Nyangka. To the west of Waanyi, languages belonging to the Barkly language family were spoken (Harvey 2008). The Waanyi data presented herein are drawn principally from my 2000-2005 recordings of the late Mr Roy Seccin 
FF (kangku), FM (ngawijilngabuji), MM (kukudilkuku) and MF (mimi). ${ }^{3}$ Unlike comparable systems such as the Warlpiri (Laughren 1982), Waanyi lexifies the male/female distinction for the maternal parents of ego's parents (FM and $\mathrm{MM}$ ); the term designating a parent's mother and her sisters differs from the one designating her brothers. For the FM relationship, ngawiji (FM[Z]) is formally distinguished from ngabuji (FMB); for the MM relation, kukudi (MM[Z]) is distinguished from $k u k u$ (MMB). The kin identified as the paternal parents of ego's parents are referred to by terms that apply to both male and female members of these sibling sets: kangku denotes any member of the FF set (FF, FFB and FFZ), while mimi denotes any member of the MF set (MF, MFB and MFZ). ${ }^{4}$ The sex distinctions encoded by the terms for members of ego's FM and MM sibling sets in the speech of the late Mr Roy Seccin reflect those for the spousal relation, which is a special case of the FM relationship: nawi 'husband $(\mathrm{H})$ or husband's (senior) brother $(\mathrm{HsB})$ ' and mangkarri 'wife (W) or wife's sister (WZ)'. Waanyi also distinguishes 'wife' from 'wife's brother (WB)' (kayikayi), which is further distinguished from a man's sister's husband (nabinabi). ${ }^{5}$ Sex is also lexically distinguished in the senior sibling relationship (members of the same subsection as FF kin): bawa (senior) 'brother' and balala or maju 'senior sister'. It is not distinguished in the junior sibling terms dawirri or kakulu. ${ }^{6} \mathrm{Sex}$ is also marked in ascending disharmonic relations: father or father's brother versus father's sister; mother and mother's sister versus mother's brother; and mother's male versus female cross-cousins (MMBS/D). However, no gender distinction is marked for father's cross-cousins (FMBS/D), who belong to

Kamarrangi and my 2007-2008 recordings of the late Mr Eric King Balyarrinyi, and supplemented by Elwyn Flint's 1964 recordings of Waanyi speakers at Doomadgee, Gavan Breen's field notes and transcriptions of recordings made with several Waanyi speakers in the 1960s and 1970s, work by Charles Osborne (1966) based on his own fieldwork, and John Dymock who recorded Waanyi language over a lengthy period between the 1960s and mid-1990s.

3 Abbreviations for kin relations are $\mathrm{F}=$ father, $\mathrm{FF}=$ father's father, $\mathrm{M}=$ mother, $\mathrm{MF}=$ mother's father, $\mathrm{FM}=$ father's mother, $\mathrm{MM}=$ mother's mother, $\mathrm{S}=$ son, $\mathrm{D}=$ daughter, $\mathrm{H}=$ husband, $\mathrm{W}=$ wife, $\mathrm{B}=$ brother and $\mathrm{Z}=$ sister. $\mathrm{F}$ and $\mathrm{M}$ are also used to designate more abstract paternal and maternal relationships respectively. Parentheses are used to indicate possible inclusion in the denotation of a term (e.g. H(B) is to be read as 'husband or husband's brother'). A forward slash between symbols indicates 'or' as in $\mathrm{B} / \mathrm{Z}$ meaning 'brother or sister'. The symbols ' $\mathrm{s}$ ' and ' $\mathrm{j}$ ' are used to indicate 'senior' versus 'junior' kin relations (e.g. sB 'senior brother' versus jB 'junior brother'). Appendices 2 and 3 display the Waanyi kintrems, non-affinal and affinal, respectively.

4 Mimi also denotes the child of ego's father's sister (FZS/D), as well as MF(Z/B) and BDS/D.

5 The distinction between $\mathrm{H}(\mathrm{B})$ (nawi) and $\mathrm{HZ}$ is probably encoded as well, but I have not recorded a term for the latter relationship, and have not found it recorded in other sources.

6 The term dawirri has been recorded as either 'junior brother' or 'junior sister' by Breen, Osborne and Dymock, in addition to kakulu recorded by Dymock (1993). Both terms are found in the Seccin corpus. Breen, Flint and Osborne record balala 'elder sister', both balala and maju are recorded by Dymock (1993), while only maju (also the Garrwa term) is in the Seccin corpus. 
the same subsection as Ego's maternal child (ZS/D). Sex distinctions are only encoded in the descending disharmonic generation kin terms for the children of ego's female cross-cousins (MBDS/D)—members of the same subsection as (MMBS/D).

All 'grandparent' terms may be used reciprocally as 'grandchild' terms, although there are additional specific 'grandchild' terms. ${ }^{7}$ In the Seccin corpus, the MM relation kuku/kukudi (ascending) contrasts with the descending ngurrali (ZDS/D). There is also a more general 'grandchild' term murimuri that is sometimes used in place of the corresponding 'ascending' term. ${ }^{8}$

Waanyi kinship terms are listed for reference in Appendices 2 and 3.

\section{Aims}

In this chapter, I explore possible explanations as to why these patterns of asymmetrical distinctions in the encoding of both sex and generation level are found within the set of harmonic generation kin terms. First, I outline the salience of these distinctions with respect to the marriage alliance and wife-bestowal system, in which a daughter is bestowed by her father on his upper generation male relative, who is the son of the bestower's MM, and by her mother on the son of her MMB. Thus, sons-in-law for both men and women are children of kin in their MM class. Such a system involves wife exchange between male cross-cousins (maku) (MBS) of each other's

7 The neighbouring and closely related Garrwa language encodes the ascending versus descending, as well as the more general senior versus junior distinction (e.g. aunt/niece and mother-in-law/ daughter-in-law) by the addition of a suffix -nya to designate the descending/junior term (Mushin 2012, pp. 47-8). Breen also recorded this usage for Waanyi (GB-Tape571-IG and GB-Tape572-IG), as did Osborne and Dymock, but not Flint. I did not record a productive systematic use of this suffix and will not discuss it in this chapter.

8 Breen recorded murimuri as the descending (grandchild) counterpart of kangku (FF) only. In the Seccin corpus, it is sometimes used as a reciprocal for both kangku (FF) and $k u k u$ (MMB). Mushin (2012, p. 48) recorded Garrwa murimuri as the grandchild counterpart of kangku (FF), kukulil kukudi (MM) and mimi (MF), even though these forms also occur with the 'junior/descending' suffix -nya. Interestingly, Garrwa kangku-nya does not denote a descending FF relationship, but rather the FFZ relationship (see discussion of the Wambaya feminine suffix -nya in the subsection 'Barkly Languages and Other Non-Pama-Nyungan Neighbours'). Thus, murimuri seems to designate descending harmonic kin relations not in the class of ego's FM (from which a spouse is drawn) - that is, ngawuji. This would seem to correspond to the wider uses of kangku recorded for Garrwa by Mushin (2012, p. 48) as a 'grand-uncle' term. The stem muri is recorded in the non-Pama-Nyungan Marra spoken north of Yanyula along the western coast of the Gulf of Carpentaria for both ascending and descending members of either sex of ego's FF set; the reduplicated form murimuri is a vocative form (Heath 1981, p. 115), which is compatible with its use in Garrwa and Waanyi as a grandchildreferring term, as well as the form most likely to be borrowed. 
sister's daughter's daughter (ngurrali)—a descending MM kinswoman. ${ }^{9}$ A further impetus towards the lexical encoding of the sex of ego's parents' maternal parent (and members of their sibling class) is the lexical marking of a sex contrast in the spousal terms, as well as in affinal terms, denoting siblings of a spouse. ${ }^{10}$ Second, I show that the Waanyi pattern of marking sex contrasts is not the necessary consequence of a Waanyi-type marriage alliance and wife-bestowal system, since the Warlpiri language does not make these distinctions, despite the Warlpiri system of marriage alliance and wife bestowal being equivalent to the Waanyi one. However, key generation levels are marked in both languages. Third, by comparing the Waanyi harmonic ascending and descending kin terminology with that of neighbouring languages - starting with closely related Garrwa followed by languages of the Warluwarric, Tangkic and Barkly groups-I show that the Waanyi lexical pattern conforms to a wider regional one. I explore the sources and indications of direction of borrowing of Waanyi terms that encode both sex and generation level contrasts within the asymmetrical pattern of linguistically encoded contrasts in harmonic generation terms. On the basis of a further comparison with the slightly more distant Marra and Alawa, I suggest that the regional pattern that is found in the Gulf area may have emerged from a series of innovations that were motivated by changes in the system of wife and brother-in-law bestowal.

\section{Organisation of Chapter}

Following the introductory material, relevant elements of the Waanyi kinship system and terminology are set out in the section "Waanyi Kin Terms' that show how the affinal relation terms mesh with the system of kin relation terms, based on maternal and paternal lines of ascent and descent. In the section 'Two Arandic Systems Compared: Waanyi and Warlpiri', the Waanyi terminology is compared with the Warlpiri. Although both groups have the same underlying system of kin relations and systems of marriage bestowal and exchange, Warlpiri kin terms do not encode the sex distinctions marked in Waanyi FM, MM and spousal terms. In the section 'Waanyi and Neighbouring Languages', Waanyi terms are compared with those expressing the same relations in languages

9 I recorded makungu as female cross-cousin. Breen and Osborne recorded makungu as 'cousin' (not distinguishing sex).

10 The practice in some kinship studies of excluding 'spousal' relations from affinal (in-law) relations does not reflect the denotation of kin terms in the Australian context, since the morpheme for 'spouse' typically also applies to the spouse's (same sex) sibling. I include 'spousal' terms in the class of 'affinal' terms. 
of the groups that are the immediate neighbours of Waanyi-starting with Garrwa, the language most closely related to Waanyi, forming with it the Garrwan group (or family) (O'Grady, Voegelin \& Voegelin 1966) and extending to languages of the Warluwarric, Tangkic and Barkly groups. Relevant data from the non-Pama-Nyungan Marra and Alawa languages spoken to the north-west of the Garrwan languages and their immediate neighbours are examined. Similarities and differences in the lexical patterns in these languages are explored, revealing cognates and borrowing patterns. The major findings of an analysis of the distribution of forms and lexical patterns across the languages surveyed are presented in the section 'Conclusions'.

\section{Waanyi Kin Terms}

Like other Australian kinship vocabularies, each term can denote a wider set of kin than do kinship terms in modern Indo-European languages. Australian kinship systems are classificatory, in that all persons are included in a relationship class that (potentially) contains members consanguineally (or by adoption) related to Ego (see Scheffler [1978] for relevant discussion). The system of kin relation terms is based on combinations of the two basic relationships: maternal and paternal (Laughren 1982, 2001). Further distinctions may be lexically marked with respect to ascending versus descending relationships, sex, seniority within sibling sets in the harmonic (Ego's and Ego's grandparents and grandchildren) and disharmonic (Ego's parents and Ego's children) generation moieties. However, apart from the maternal/paternal distinction and the harmonic/ disharmonic distinction, other distinctions such as sex and seniority are not encoded for all kin categories. ${ }^{11}$

Affinal relationships are grafted onto this same system, as they are entered into with a subset of kin restricted by marriage 'laws' and conventions, as well as established or negotiated systems of wife exchange and wife bestowal between particular family groups. Some affinal relationships are marked by special terms that are substituted for the more general nonaffinal terms; others remain unmarked. ${ }^{12}$

11 Primogeniture plays a crucial role in determining seniority in ego's generation as an inherited feature from the grandparent generation via the parent generation.

12 Only the most favoured or 'first choice' marriage pattern is described herein. Less restrictive spousal alliances between members of the same generation moiety, such as between a man and his classificatory MBD or ZSD, or his MMBSD or ZDD, are also entered into. 


\section{Waanyi Harmonic Generation Kin Terms}

The terms that distinguish kin in the ascending harmonic (grandparent) generation from Ego are shown in Figure 46. ${ }^{13}$ Paternal relations (marked by a solid line) are distinguished from maternal relations (marked by a broken line). Terms for Ego's 'mother' and 'father' are also shown.

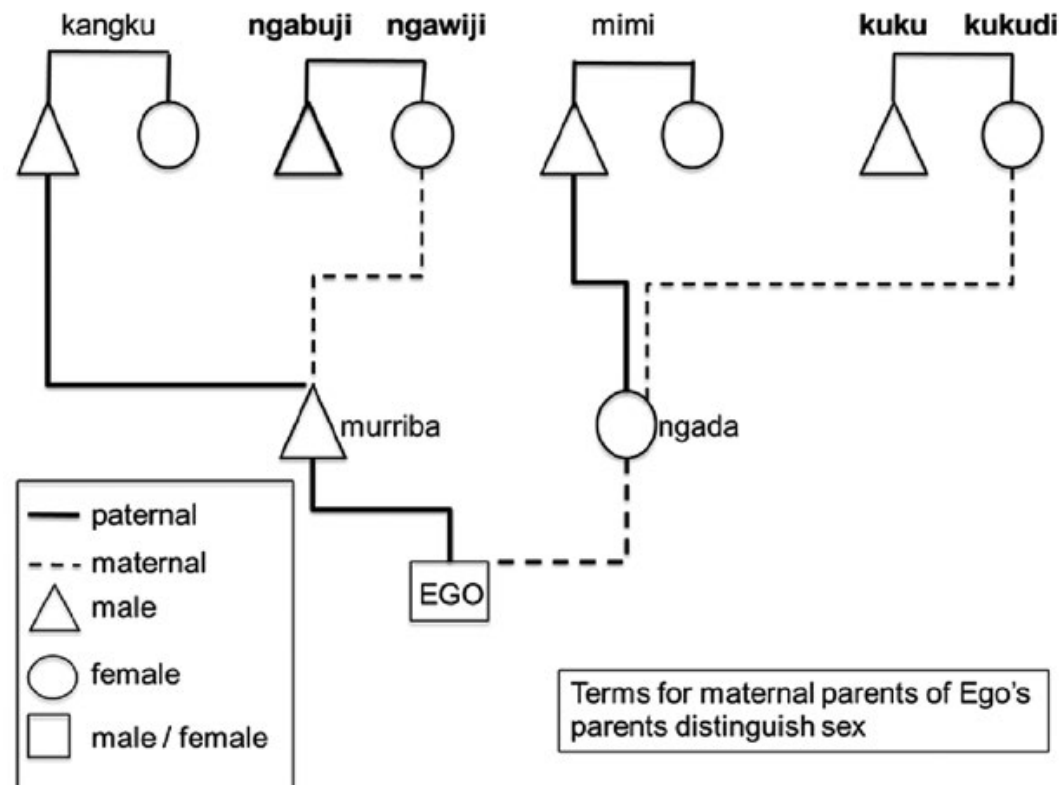

Figure 46: Waanyi ascending harmonic generation kin terms.

Source: Author's work.

Only the terms denoting ego's parents' maternal parent sibling sets distinguish male from female members. The male members of the FM set are called ngabuji, a phonologically more conservative cognate containing the stop /b/ of ngawiji, with the lenited glide /w/, which denotes the female members. Given the widespread existence of the /b/ form (e.g. ngabuji, ngabuju and other variants) with same or related meanings in many languages of northern Australia extending west of Waanyi, this form is likely to have entered Waanyi later than the $/ \mathrm{w} /$ form. ${ }^{14}$ The terms for

13 The kin terms shown in each of the figures can be used by Ego to refer to any member of the designated set or class; thus, each triangle, circle or rectangle should be interpreted as representing a sibling set, as well as any member of that set.

14 Waanyi shows evidence of an historic lenition of $/ \mathrm{b} /$ to $/ \mathrm{w} /$ in intervocalic position in pre-Waanyifor example, bawa 'elder brother' < *baba, or nawi 'husband' <*nabi (cf. nabinabi 'brother-in-law'). 
$\mathrm{MMB}$ and $\mathrm{MM}(\mathrm{Z})$ are related in a different way; they share the same root, $k u k u$, but the female term has the historical kin suffix -di (written -rdi or $-r t i$ in other languages), which is widely distributed across Australian languages. ${ }^{15}$ Kukudi is the only Waanyi kinterm that unambiguously contains this suffix that is not productive in either Waanyi or Garrwa. ${ }^{16}$ It has been borrowed into Waanyi as a monomorphemic word to mark the sex distinction between $\mathrm{MM}(\mathrm{Z})$ and $\mathrm{MMB}$ in the same way that ngabuji has been borrowed to distinguish $\mathrm{FMB}$ from $\operatorname{FM}(\mathrm{Z}) .{ }^{17}$

This chapter explores the motivation for lexically marking the sex distinction in these two sets of ascending harmonic relations, the maternal parents of ego's parents (FM and MM), as opposed to the other two sets, made up of individuals that are paternally related to ego's parents (FF and MF). While harmonic terms do not generally encode the ascending (grandparent) versus descending (grandchild) distinction, such a distinction is marked in the MM set, since a specific 'descending' term ngurrali contrasts with the more general kukulkukudi pair, as shown in Figure $47^{18}$ - this is the second anomaly to be examined. This lexicalised distinction between grand-uncle (MMB) and grandnephew/niece (ZDS/D) was explained to me by Roy Seccin in referring to his sister's daughter's son: 'Like I call him ngurrali, he call me kuku' (Roy Seccin Kamarrangi, 04Tape6, 2002). As symbolised by the square shapes in Figure 47, the descending term applies to either male or female referents. Figure 47 also shows that while paternal children jawaji (man's or brother's children) are distinguished from maternal children jabulu (woman's or sister's children), the sex of these children is not distinguished by these terms.

15 See Nash (1992) for a comparative study of this morpheme that was reprised by McConvell (2008). This suffix has not been found to denote 'female' or mark feminine gender, but rather marks a first-person (speaker) propositus where productive, as in Marra (Heath 1981).

16 Waanyi and Garrwa kadidi MB may also contain this suffix-although it may also reflect stem final syllable reduplication.

17 The typical Australian contrast between alveolar and post-alveolar consonant sounds is highly restricted in Waanyi (Breen 2003); sounds symbolised by $d, l$ and $n$ are usually pronounced with a post-alveolar articulation.

18 Other sources record kukulinya, and not ngurrali, as the descending term. A reviewer pointed out that neither Osborne nor Breen recorded kuku as MMB; however, Breen (Ivy George, tape no. 569 , side 1) recorded kujawuja as MMB, in contrast with MM kukudi or kukuli, which are both terms that were also recorded by Flint and reproduced in the Seccin corpus. Whether the MMB term is kuku or kujawuja, in lexical contrast with MM kukudi, remains to be explained. Osborne (1966) recorded kujawaja as 'grandfather' without further specifying, while Dymock (1993) listed kujawuja as FF, along with kangku. 


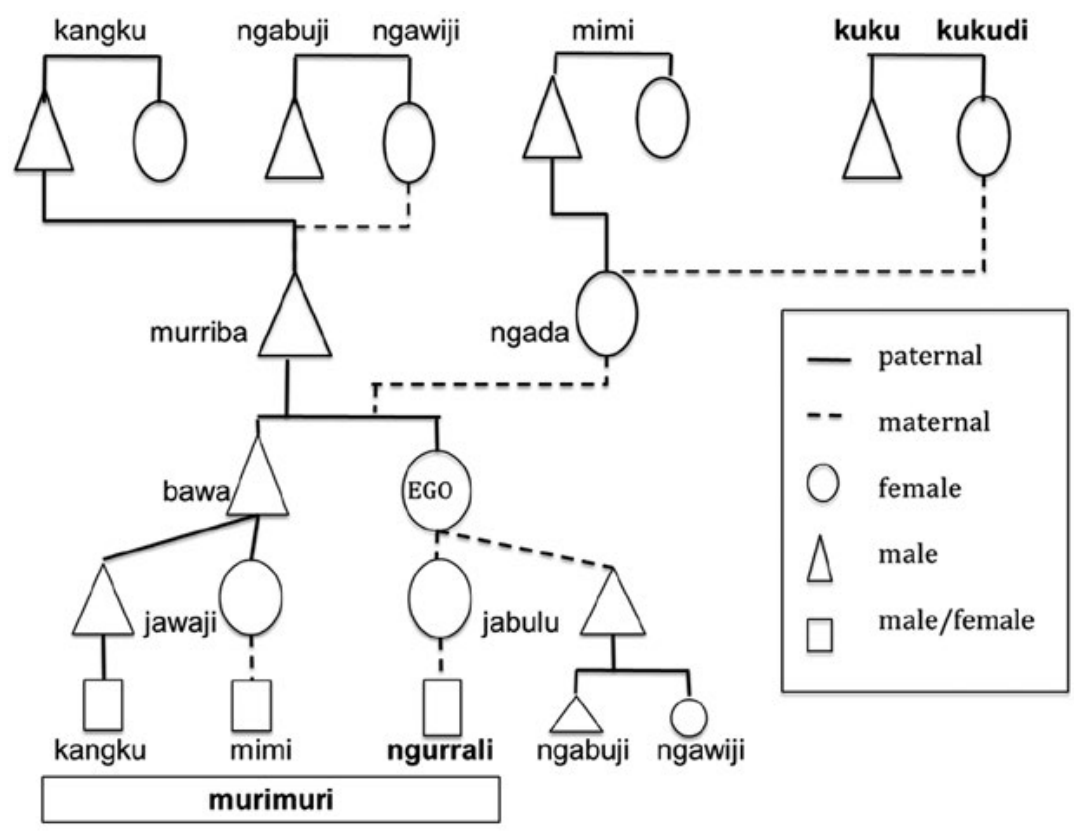

Figure 47: Waanyi ascending and descending harmonic generation kin terms.

Source: Author's work.

We now address the question of the possible motivation for these somewhat anomalous distinctions in terms of the overall system of kin relationships: why is the sex distinction limited to Ego's parents' maternal parents, and why is the ascending/descending relationship lexically marked with distinct terms that only denote kin in an MM relationship? Is there anything that makes these particular relationships special, or that distinguishes them from the others in terms of social roles? The first line of enquiry I explore is the role that these relationships play in wife bestowal and exchange, and the way that affinal relationships and terminology intermesh with non-affinal relationships and terminology in Waanyi.

From a woman's point of view, as shown in Figure 48, her nawi 'husband' belongs to the male set of FM ngabuji kin, while from a man's point of view, it is his sister's husband nabinabi who belongs to the ascending ngabuji set, as shown in Figure 49. ${ }^{19}$

19 In the neighbouring Tangkic language Yukulta, nabinabi is 'wife's brother' (Keen 1983, p. 291), while in the northern Warluwarric language Yanyula, it is recorded as 'sister's husband' (Bradley 1992, p. 509). 


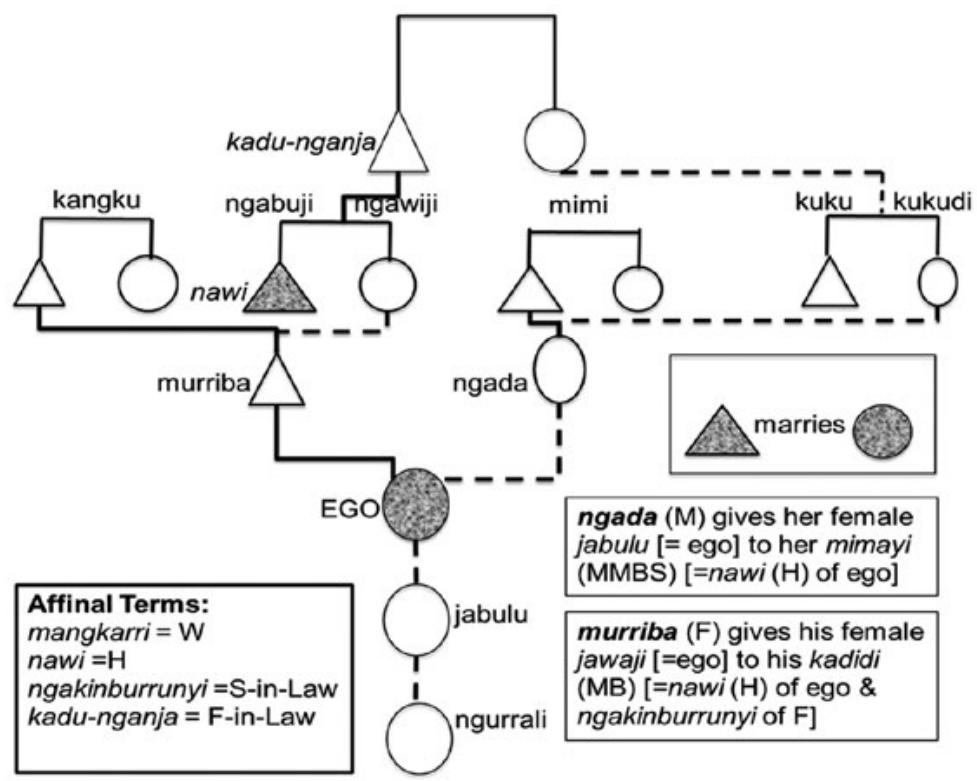

Figure 48: Waanyi pattern of wife bestowal..$^{20}$

Source: Author's work.

It follows then that a man's mangkarri 'wife' and kayikayi 'wife's brother' belong to the descending set of FM ngawijilngabuji kin. Thus, the sex distinction in the spousal terms — nawi $(\mathrm{H}[\mathrm{B}])$ versus mangkarri $(\mathrm{W}[\mathrm{Z}])$ is reflected in the non-affinal terms that refer to the larger kin sets: ngabuji (male) versus ngawiji (female).

Figure 49 shows how a man's father-in-law (kadu-nganja) belongs to the class of his sister's son (jabulu), while his (senior) brother-in-law (nabinabi), who is his sister's husband, belongs to the set of his ascending ngabuji (FM) ${ }^{21}$ His wife (mangkarri) and her brother (man's [junior] brother-inlaw called kayikayi) belong to the set of his descending female ngawiji and male ngabuji respectively. ${ }^{22}$ While Figure 48 shows how a woman marries a member of the set of her father's mother's brother, a man should not marry a woman whom his father calls ngada 'mother', as indicated by the barred circle in Figure 49.

20 In Figures 48 and 49, the affinal terms are in italics, while the non-affinal terms are in plain typeface.

21 The term kadu-nganja, the Garrwan 'father-in-law' term, is mentioned in the footnote on mimayi in Table 57.

22 Kayikayi (written in Alawa and Marra as gaygay) is quite widely distributed as a 'brother-in-law' or 'spouse' term in languages spoken in the south-west Gulf of Carpentaria region. 


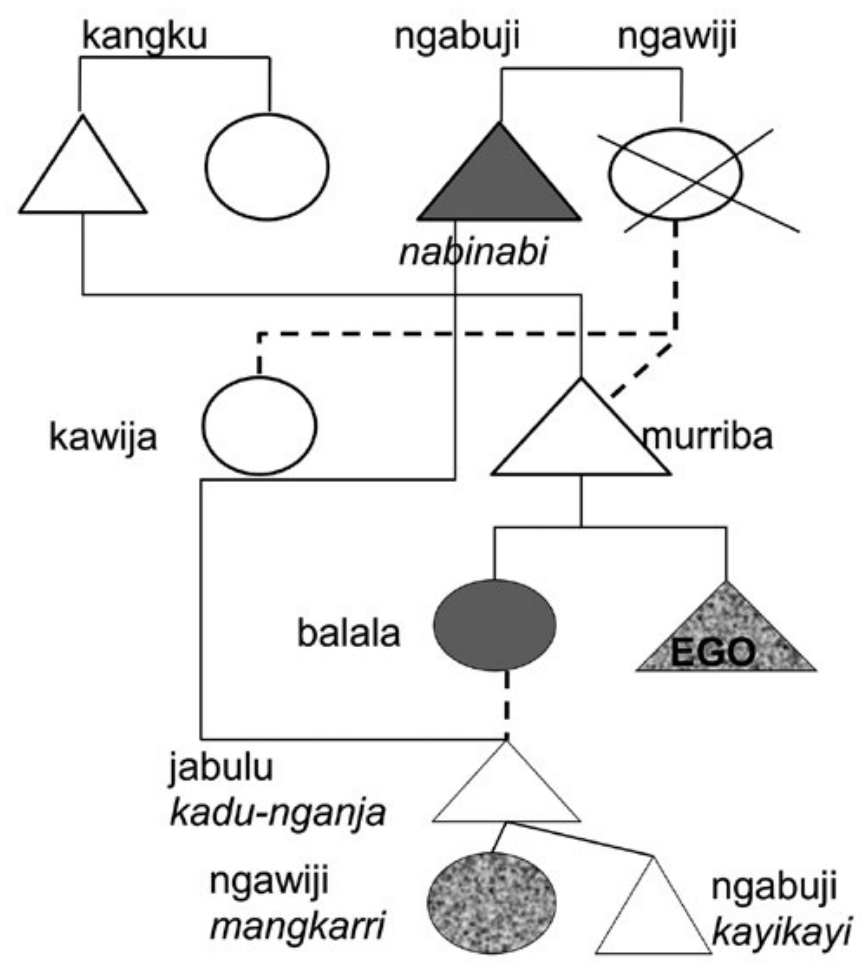

Figure 49: Asymmetrical brother-in-law relationship.

Source: Author's work.

The data in Figures 48 and 49 show that affinal terms encode more semantic distinctions than do non-affinal harmonic generation terms. While terms such as nawi $(\mathrm{H})$ and mangkarri (W) encode sex distinctions, as do their non-affinal counterparts ngabuji (FMB) and ngawiji (FM[Z]), the former pair also encode the ascending/descending distinction through their respective correspondence with the brother-in-law terms that distinguish nawi, ascending members of the ngabuji set, from kayikayi, (descending) members of the ngabuji class. Again, the distinction between mangkarri 'wife' and kayikayi 'wife's brother' mirrors the sex distinction between ngawiji and ngabuji, and both contrast with the ascending generation terms, nawi 'husband' and nabinabi '(man's) sister's husband'. These contrasts are summarised in Table $56 .{ }^{23}$

23 A reviewer pointed out that ngabuji is not recorded by either Breen or Osborne. I could only find a term for father's mother and none for father's mother's brother in these works, so the absence of ngabuji does not entail that this term is a recent borrowing into Waanyi, since it was not elicited. Both terms were recorded by Trigger (1982, p. 26). 
Table 56: Waanyi terms for relations in FM class.

\begin{tabular}{|l|l|l|l|l|}
\hline & \multicolumn{2}{|l|}{ AFFINAL TERMS } & \multicolumn{2}{l|}{ NON-AFFINAL TERMS } \\
\hline & Male & Female & Male & female \\
\hline ascending & $\begin{array}{l}\text { nawi } \mathrm{H}(\mathrm{eB}) \\
\text { nabinabi } \mathrm{ZH}(\mathrm{B})\end{array}$ & ? HZ & $\begin{array}{l}\text { ngabuji } \\
\text { FMB/ZSS }\end{array}$ & $\begin{array}{l}\text { ngawiji } \\
\text { FM(Z)/ZSD }\end{array}$ \\
\hline descending & kayikayi HjB/WB & mangkarri W(Z) & & \\
\hline
\end{tabular}

Source: Author's work.

Considering the lexical pattern discussed above, it is possible that the gender distinction in the FM non-affinal terms followed the introduction of affinal terms marking gender distinctions. Ngawiji may have narrowed its meaning to designate female-only members of the FM class when the male term ngabuji was introduced. We return to this question in the section 'Waanyi and Neighbouring Languages'.

As shown in Figures 46-48, the other grandparent relation, whose male and female members are called by distinct but related terms, is the MM relationship, which plays a key role in wife bestowal. As already mentioned, a person (male or female) bestows their female jabulu 'maternal child' on their mimayi 'son-in-law', who is the male paternal child of a member of their MM class (i.e. of their mother's mother's brother [= kuku]). As for their female jawaji 'paternal child', she is bestowed on their kadidi 'mother's brother', who is the maternal child (MMS) of a member of their MM class (i.e. the son of their kukudi). ${ }^{24}$ Thus, we see that the MM (kukulkukudi) relation plays a key role in wife bestowal. A man bestows his daughter on the son of his female kukudi, while a woman bestows her daughter on the son of her (male) $k u k u .{ }^{25}$ While the relationship between a man and his son-in-law (= kadidi 'uncle') remains within the same matrimoiety and does not call for strict avoidance behaviour, a woman is in the opposite matrimoiety to her son-in-law (= mimayi)—a relationship that is marked by elaborate avoidance conventions. Thus, the lexical marking of the contrast between male and female members of one's MM

24 Waanyi has a range of terms for MB including kamburru 'senior uncle' and kabubu 'junior uncle', as well as kadidi. The conditions that determine the use of kadidi, as opposed to the other two terms, are uncertain.

25 Trigger (1982, pp. 26-7) recorded Waanyi gugudi MM(Z) contrasting with kangku (MMB) and $\mathrm{FF}(\mathrm{B} / \mathrm{Z})$. Mushin $(2012$, p. 48) recorded a similar distribution of terms for Garrwa. The transitive relationship verb $k u k u-m b a$ 'be $\mathrm{MM}(\mathrm{B} / \mathrm{Z})$ to' is built on the stem $k u k u$ that is unmarked for sex. Irrespective of the term used to distinguish $\mathrm{MMB}$ from $\mathrm{MM}(\mathrm{Z})$, what is salient to this discussion is the fact that the sex distinction is lexified for nouns. 
class would seem well motivated from a functional or social perspective, since their paternal children are potential sons-in-law and mothers-in-law. These relationships are summarised in Table 57.

Table 57: Son-in-law ngakinburrunyi relationships. ${ }^{26}$

\begin{tabular}{|l|l|l|}
\hline AFFINAL & NON-AFFINAL & \\
\hline ngakinburrunyi 'son-in-law' of man & child of kukudi = kadidi & $\begin{array}{l}\text { same matrimoiety, } \\
\text { non-taboo }\end{array}$ \\
\hline ngakinburrunyi 'son-in-law' of woman & child of kuku= mimayi' & $\begin{array}{l}\text { other matrimoiety, } \\
\text { taboo 'poison cousin' }\end{array}$ \\
\hline
\end{tabular}

Source: Author's work.

${ }^{1}$ Mimayi has the same meaning in the Barkly language Wambaya (Nordlinger 1998, p. 287). In Alawa (Sharpe 2001, p. 72) and Marra (Heath 1981, p. 119), -mimay is an affinal 'spouse' root, which may host a gender affix. Breen recorded kuwana-nganja 'daughter/son-in-law' (also cited for Garrwa by Mushin on the basis of Trigger's field notes) and mandawalanganja 'father-in-law' of the female speaker. Osborne and Flint only recorded kadu-nganja 'father-in-law' - the term used by Seccin.

I now turn to the other anomaly shown in Figures 46 and 47, whereby it is only in the MM grandparent class that the ascending/descending distinction is specifically marked by lexically distinct terms in Seccin's speech. What is distinctive about the MM grandparent-grandchild distinction that might motivate the lexical marking of this distinction?

Another aspect of wife bestowal is the practice of wife exchange between men who are cross-cousins, and thus members of opposite patrimoieties and matrimoieties, who call each other maku or mimi. These men 'exchange' their female ngurrali (ZDD) as marriage partners; these women call their MMB kuku. Thus, we see that the asymmetry between ascending and descending members of the MM set is socially marked as a relationship between wife giver and wife receiver. This pattern of wife exchange is mediated by mother-in-law bestowal: a man bestows his sister's daughter (jabulu) as mother-in-law (ngunyarri) of his cross-cousin (mimilmaku), who belongs to the same superset as his mother's father (mimi). His own child is a potential son-in-law/mother-in-law of his ngurrali.

The key relationships involved in this practice of wife exchange are shown in Figure 50.

26 The literal meaning of ngaki-n-burru-nyi is 'one towards me/mine' (ngaki is first-person dative pronoun). The suffix -nyi is frequently used on kin terms in Breen's Waanyi recordings-seemingly marking a vocative or citation usage. Mushin (2012, p. 49) cited burrunyi as a S/D-in-law term. 


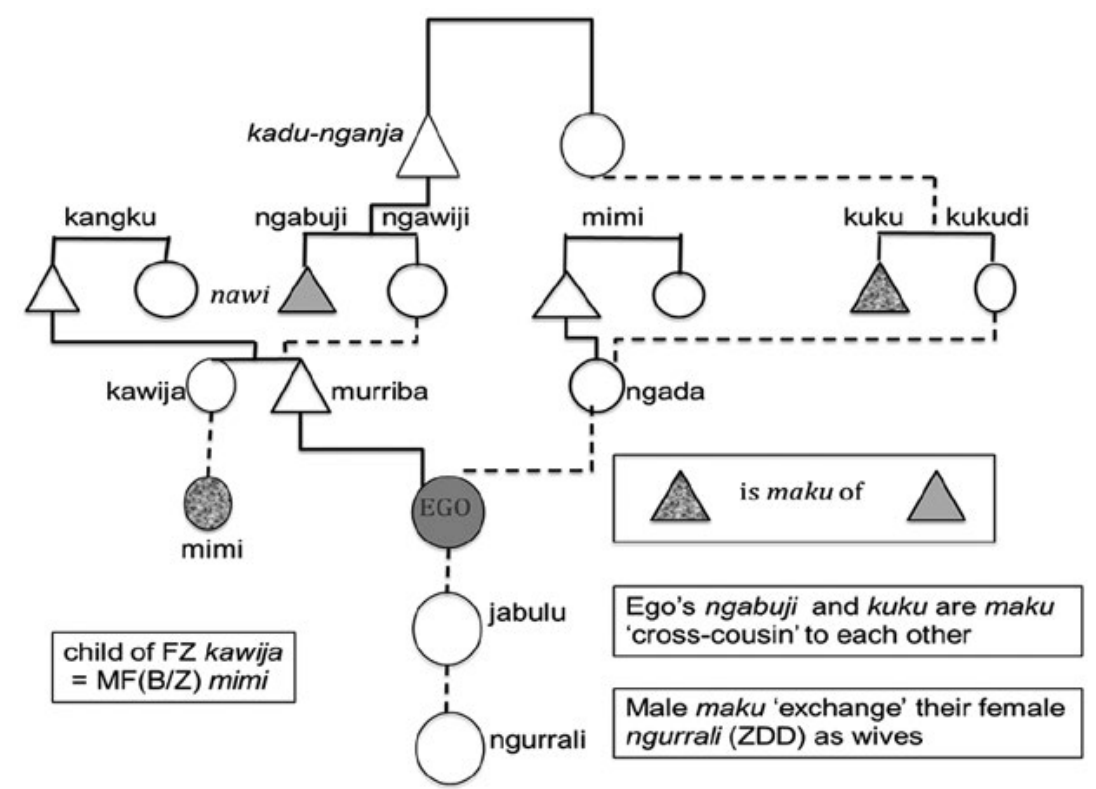

Figure 50: Pattern of wife exchange between cross-cousins.

Source: Author's work.

Figure 50 shows how the nawi $(\mathrm{H})$ of female Ego belongs to the class of her ngabuji (FMB) - the maku ('cross-cousin') of ego's kuku(di) (MM[B/ Z]). ${ }^{27}$ This kuku would refer to Ego as his ngurrali. Ego's kuku is married to Ego's mimi, who is the child of Ego's kawija (FZ) and the ngurrali (ZDD) of Ego's nawi $(\mathrm{H})$. The mother-in-law exchange illustrated in Figure 50 involves ego's M (ngada) and ego's FZ (kawija).

\section{Summary}

What we've shown so far is that the anomalous marking of sex and ascending/descending distinctions in Ego's 'grandparent/child' generation correlates with distinctive roles in the traditional practice of wife bestowal and exchange. A woman's husband is drawn from the set of her male ascending FM kin, her ngabuji, while conversely a man marries a wife from his descending FM kin, his ngawiji. The gender distinction encoded in these non-affinal terms mirrors the gender distinction encoded in the corresponding affinal terms, nawi $\mathrm{H}(\mathrm{eB})$ and mangkarri $\mathrm{W}(\mathrm{Z})$. The gender distinction in the MM terms kuku and kukudi marks the

27 Flint also recorded mimi as both MF and MBS, but makungu as MBD. 
salience of this relationship in the system of wife bestowal involving cross-cousins. The marking of the descending MM category by the term ngurrali, which contrasts with the ascending terms kuku and kukudi, also correlates with the distinctive roles of wife bestower $(k u k u)$ and bestowed (ngurrali) within this pattern of wife exchange. The terms that specify a 'female' member of the FM and MM grandparent relationships apply to the maternal parent of ego's father-in-law and mother-in-law-these relationships being highly taboo in traditional Waanyi society. A man's father-in-law is the son of his wife's ngawiji, while his mother-in-law is the daughter of his wife's kukudi, as shown in Figure 50, where 'wife' is ego. However, as will be seen in the next section, there is no necessary relationship between this marriage pattern and the lexical pattern found in Waanyi ascending and descending harmonic terms.

\section{Two Arandic Systems Compared: Waanyi and Warlpiri}

Waanyi and Warlpiri ${ }^{28}$ kinship systems are virtually identical with respect to their systems of marriage alliance, wife bestowal and exchange. However, an examination of Warlpiri grandparent/child terms reveals that the lexical marking of gender distinctions in ascending harmonic generation terms for the maternal parents of ego's parents found in Waanyi is not a necessary concomitant of this system of wife bestowal and exchange. However, I argue that these lexical contrasts are not random, but reflect key social distinctions at the core of the shared system of affinal kin relationships.

\section{Warlpiri Ascending/Descending Harmonic Generation Kin Terms}

No gender distinction is lexified in the Warlpiri nomenclature for harmonic ascending and descending non-affinal kin terms. As in Waanyi, identical terms are used for both ascending (grandparent) and descending (grandchild) sets. However, we find the same anomalous pattern as seen

28 Warlpiri is a Pama-Nyungan language of the Ngumpin-Yapa group (McConvell \& Laughren 2004) spoken in an area over $1,000 \mathrm{~km}$ to the south-west of the Waanyi-speaking area. These languages were traditionally separated by the non-Pama-Nyungan Barkly languages and the PamaNyungan languages of the Warluwarric, Arandic and Warumungu groups. See Figure 52. 
in Waanyi with respect to the MM set. The ascending MM term jaja may be replaced by a specifically descending generation term mirntirdi. ${ }^{29}$ Additionally, the ascending and descending FM relations may be distinguished by the use of yapirliyi (derived from Arandic * aperl plus the first-person propositive suffix -ey) for the descending term in opposition with the unmarked term yaparla (ngapuju is used in place of yaparla or yaparliyi in north-western or Lajamanu Warlpiri). ${ }^{30}$

\section{Waanyi and Warlpiri Compared}

A comparison of relevant Waanyi and Warlpiri kin terms is shown in Figure 51.

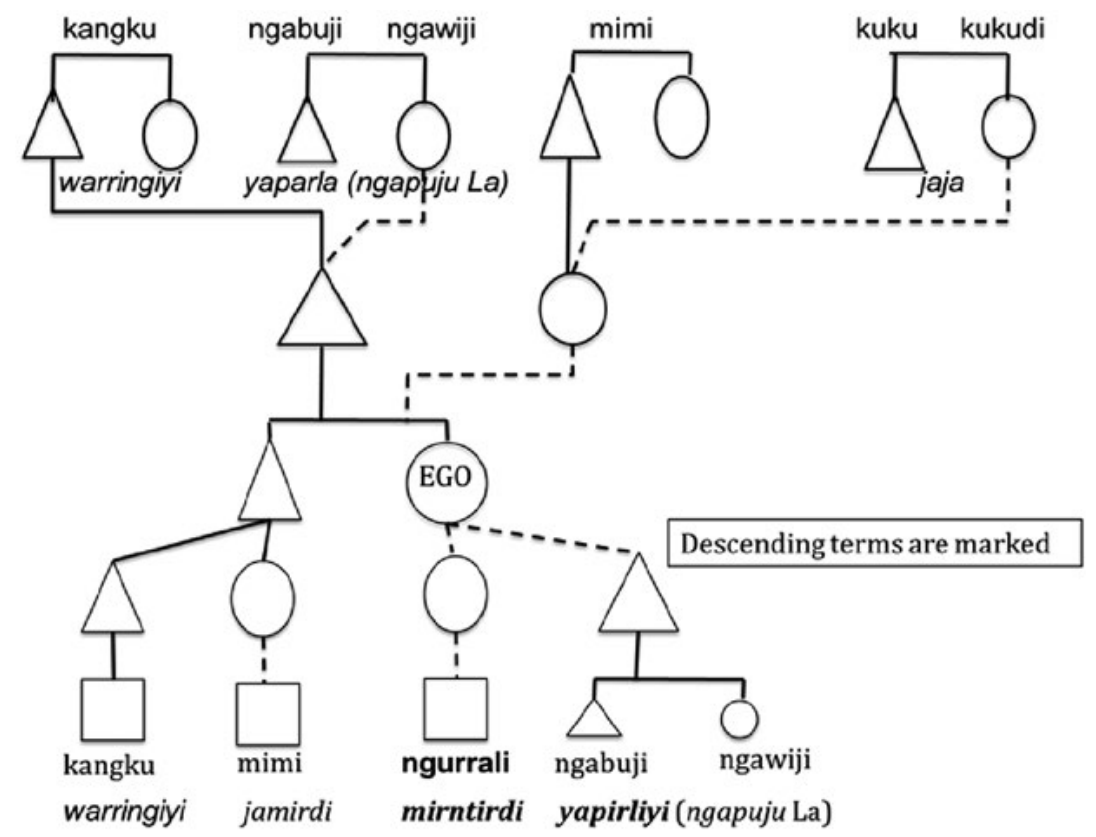

Figure 51: Waanyi and Warlpiri grandparent/child terms compared. ${ }^{31}$ Source: Author's work.

29 This term may be cognate with Wakaya mintara (Spencer, cited in Breen 2000c).

30 The terms ngapuju and yapirli are used to designate the spousal relationship between specific ascending and descending disharmonic kin respectively: ngapuju refers to the spouse of speaker's father or mother, or father's brother or sister (but not of mother's brother), while yapirli refers to the spousal relation between female speaker's brother's son and his wife (speaker's MBSD). Warlpiri ngapuju is clearly cognate with both Waanyi ngabuji and ngawiji.

31 In Figure 51, the Waanyi terms are written in plain typeface above their Warlpiri counterpart in italics. Terms that are specifically 'descending' are in bold face. 
Another relevant way in which Warlpiri kin terminology differs from Waanyi is in the use of the same term to refer to both husband and wife (i.e. kali), with the special dyadic suffix -nja denoting a husband and wife pair. ${ }^{32}$ Thus, the Warlpiri spouse term fails to encode either the sex or the generation level contrast between husband and wife. Recall that Waanyi distinguishes wife (mangkarri) from husband (nawi). As mentioned in the section 'Waanyi Kin Terms', this distinction may well have served as a trigger of sorts for making a distinction between male and female members of one's FM set from which marriage partners are drawn.

The marriage pattern shown in Figures 48 to 50 in which a woman marries up into the set of her FM while a man marries down to a ZSD was reflected in the asymmetrical brother-in-law terms in Waanyi, as shown in Figure 49. Despite the lack of differentiation in the spousal terms, Warlpiri has an identical pattern of brother-in-law terms, distinguishing a descending generation wife's brother karntiya from an ascending generation sister's husband ngumparna (kalyakana in eastern Warlpiri). ${ }^{33}$

\section{Summary}

A comparison of Waanyi and Warlpiri FM terms reveals a number of differences in the marking of the male-female distinction in terms relating to members of Ego's FM set, as shown in Table 58. Waanyi marks both sex and seniority distinctions in its affinal terms, but only sex in its nonaffinal FM terms. Warlpiri marks seniority in both affinal and non-affinal terms; however, the marking of seniority is restricted to the brotherin-law of man terms in affinal terms. The sex distinction is confined to the brother-in-law/sister-in-law distinction in that a man refers to male siblings of his wife or sister's husband by distinct terms from that used by a woman to refer to the female siblings of her husband or of her brother's wife (i.e. mantirri).

32 Kali is likely to be an old Pama-Nyungan term for 'spouse' or 'father's mother', since cognates are found in languages as geographically distant as Warlpiri, Yolngu (kali 'wife' in Yan-nhangu) and the Maric language Kangulu (kali-njila 'father's mother' recorded by Sharpe 1967).

33 Both the Warlpiri senior and junior brother-in-law terms are cognate with related terms in non-Pama-Nyungan languages spoken in the southern Gulf of Carpentaria region: karndiya 'wife' in Yukulta, containing the Proto-Tangkic root *karndi 'wife' (see Table 62); ngumbarna non-lenited stem of dyadic brother-in-law terms, related to non-dyadic wumbarna, in Marra (Heath 1981, pp. 111, 119). 
Table 58: Waanyi and Warlpiri affinal and non-affinal terms compared.

\begin{tabular}{|l|l|l|l|l|l|l|l|l|}
\hline \multicolumn{4}{|l|}{ AFFINAL TERMS } & \multicolumn{4}{l|}{ NON-AFFINAL TERMS } \\
\hline & $\mathrm{H}(\mathrm{B})$ & $\mathrm{W}(\mathrm{Z})$ & Man's ZH & WB & FMB & FM(Z) & ZSS & ZSD \\
\hline Waanyi & nawi & mangkarri & nabinabi & kayikayi & ngabuji & ngawiji & ngabuji & ngawiji \\
\hline Warlpiri & kali & $\begin{array}{l}\text { ngumparna/ } \\
\text { kalyakana }\end{array}$ & karntiya & \multicolumn{4}{|l|}{ yaparla/ngapuju } & yapirliyi \\
\hline
\end{tabular}

Source: Author's work.

As shown in the comparison of Waanyi and Warlpiri MM terms in Table 59, both languages can mark the ascending/descending generation distinction, but again only Waanyi marks the sex distinction, which is restricted to the ascending generation terms.

Table 59: Waanyi and Warlpiri MM terms compared.

\begin{tabular}{|l|l|l|l|}
\hline & MMB & MM(Z) & ZDS/D \\
\hline Waanyi & kuku & kukudi & ngurrali \\
\hline Warlpiri & jaja & mirntirdi \\
\hline
\end{tabular}

Source: Author's work.

In the section 'Waanyi Kin Terms', I argued that the pattern of lexically marked distinctions in the Waanyi grandparent/child relationships is not random, but motivated by the system of wife exchange and bestowal. This comparison with the Warlpiri pattern of corresponding affinal and nonaffinal terms shows that the pattern of sex-marking found in the Waanyi terms is not a necessary linguistic response to this system of marriage relations. In the next section, I consider the influence of language contact on Waanyi, and the implied social interaction within the Gulf region, which is one of the most linguistically diverse regions in Australia.

\section{Waanyi and Neighbouring Languages}

In this section, semantically related kin terms in the language groups neighbouring Waanyi are surveyed to see if the Waanyi lexical pattern is a generalised feature of languages spoken in the southern area of the Gulf of Carpentaria, and also to detect if there are clues as to probable patterns of lexical innovation in Waanyi and their sources. If the Waanyi pattern, as opposed to the Warlpiri pattern, is shared in this area, then the question remains as to the motivation for these asymmetrical patterns of lexical 
markedness. The existence of these distinctions in Waanyi may be seen as an adaptation to a regional pattern. If so, what motivated this lexical pattern and its spread, and how did it proceed?

\section{Waanyi and Garrwa Compared}

The language most closely related to Waanyi is Garrwa, forming a Garrwan group, in which we find a similar pattern to the Waanyi one, as shown in Table $60 .{ }^{34}$ Breen (2003) distinguished two varieties of Garrwa: eastern and western. The Garrwa data cited in this section are western Garrwataken mainly from Mushin (2012). ${ }^{35}$

Table 60: Waanyi and Garrwa harmonic ascending/descending generation and affinal terms.

\begin{tabular}{|c|c|c|c|c|}
\hline & & Waanyi & Garrwa $^{1}$ & Shared Garrwan \\
\hline \multirow[t]{5}{*}{ Affinal } & $\mathrm{H}(\mathrm{B})$ & nawi & nawu/kayikayi & nawi/u \\
\hline & $\mathrm{HZ} / \mathrm{BW}$ & $?$ & manjikarra & \\
\hline & $W(Z)$ & mangkarri & mani/ngabuji & \\
\hline & $\mathrm{mZH}$ & nabinabi & $?$ & \\
\hline & WB & kayikayi & nganawarra & \\
\hline \multirow[t]{4}{*}{ Non-affinal } & FMB & ngabuji & ngabuji/kangku & \\
\hline & $\mathrm{FM}(\mathrm{Z})$ & ngawiji & ngawuji/ngabuji & ngawiji/ngawuji \\
\hline & MMB & kuku/kujawuja & kangku & \multirow[t]{2}{*}{ kuku- } \\
\hline & $\mathrm{MM}(Z)$ & kukuli/kukudi & kukuli/kukudi & \\
\hline
\end{tabular}

Source: Author's work.

1 Bradley (1992) recorded Yanyula nganawarra 'brother-in-law' (mZH) and manjikarra 'sister-in-law' (wBW). Garrwa kayikayi is used only as an address form (Mushin 2012, p. 49). Mushin (2012, p. 48) recorded ngawuji as FM only, ngabuji as both FM and FMB and also kangku as FMB (as well as FF). Breen (n.d.) recorded only ngawiji FM in both Waanyi and Garrwa. Breen (n.d.) recorded Garrwa kukuli MM and kukudi DD. The grandparent/ child terms listed by Mushin (2012, p. 48) indicate a terminological system in flux in which the sex distinction has been extended to all ascending terms by extending the use of

34 The classification of Garrwan as Pama-Nyungan (see Harvey 2009) or non-Pama-Nyungan (see Blake 1988, 1990; O'Grady, Voegelin \& Voegelin 1966) is disputed. O'Grady (1979) placed Proto-Garrwan as a sister to Proto-'nuclear' Pama-Nyungan, while Proto-Tangkic was a sister of Proto-Garrwan-Nuclear Pama-Nyungan. See Evans (2003) for a discussion of this 'offshoot' model of genetic relationships descending from a proto-Australian node.

35 Breen (2003, p. 457) cited both mani and mangkarri as Waanyi terms for 'wife', and distinguished eastern Garrwa mangkarri from western Garrwa mani. In Roy Seccin's Waanyi speech, and also from Eric King, I recorded only mangkarri 'wife'. Flint, Dymock and Osborne recorded only mangkarri 'wife'. Osborne also glossed mangkarri as 'spouse' and 'husband'-although he also recorded nawi 'husband'. 
relational stems-for example, kangku FF, FMB and MMB, kukudi and kangku-nya FFZ, ngawuji $\mathrm{FM}$ mimi $\mathrm{MF}(\mathrm{B} / \mathrm{Z})$ of man but bujarra MFZ of woman. This last term is also MyZ in both Garrwa and Waanyi.

The distinction between husband and wife is lexically marked in both Garrwa and Waanyi: the Garrwa 'husband' term nawu is cognate with Waanyi nawi 'husband', while the 'wife' terms differ. The Garrwa alternative 'husband' term kayikayi denotes WB in Waanyi. ${ }^{36}$ Unlike in Waanyi, the Garrwa upper harmonic generation terms do not distinguish between male and female. The female-referring Waanyi FM term ngawiji is cognate with Garrwa ngawuji. Both Garrwa $\mathrm{MM}(\mathrm{B} / \mathrm{Z})$ terms kukudi and kukuli are also recorded in Waanyi by Breen and in the Seccin corpus; only kukudi is recorded by Osborne, as are the two other grandparent terms mimi MF and kangku FF. In Garrwa, the distinction between ascending and descending harmonic kin is marked by adding a 'descending' suffix -nya to the corresponding ascending term; thus, kukudi-nya or kukulinya corresponds semantically to Waanyi ngurrali in the Seccin corpus. ${ }^{37}$ As will be seen in the next section, some of the Waanyi terms that are not found in Garrwa may have had their origins in southern Warluwarric languages bordering Waanyi but not Garrwa territory.

\section{Comparison with Warluwarric Languages ${ }^{38}$}

The relationship between the Garrwan and Warluwarric languages is quite intimate in the sense that the Garrwan homeland extends from the northern and southern upstream branches of the Nicholson River in north-western Queensland to west of the Robinson River in the Northern Territory (see Figure 52), and thus separates the northern Warluwarric language Yanyula, spoken in the Borroloola area and on the adjacent Sir Edward Pellew Islands in the southern Gulf of Carpentaria, from the southern Warluwarric languages (see Blake 1990; Brammall 1991; Carew 1993). Waanyi's southern border is defined by the northern border of the Warluwarric languages Yinjirlanji and Wakaya. The documentation of Yinjirlanji is particularly poor.

36 In the Seccin corpus, kayikayi is also used to refer to husband's junior brother.

37 This suffix is also found in Breen's Waanyi data and both kukulinya and ngawujinya are recorded by Dymock (1993) as grandchild terms.

38 Breen (2004) referred to this group of languages as Ngarna languages, since they all share an innovative first-person singular nominative pronoun ngarna. However, this innovation seems to be shared with many western Pama-Nyungan languages that retain it as the first-person enclitic -rna. Hence, I have chosen to retain the earlier group name used by O'Grady, Voegelin and Voegelin (1966), drawn from the name of one of the languages of this group. 


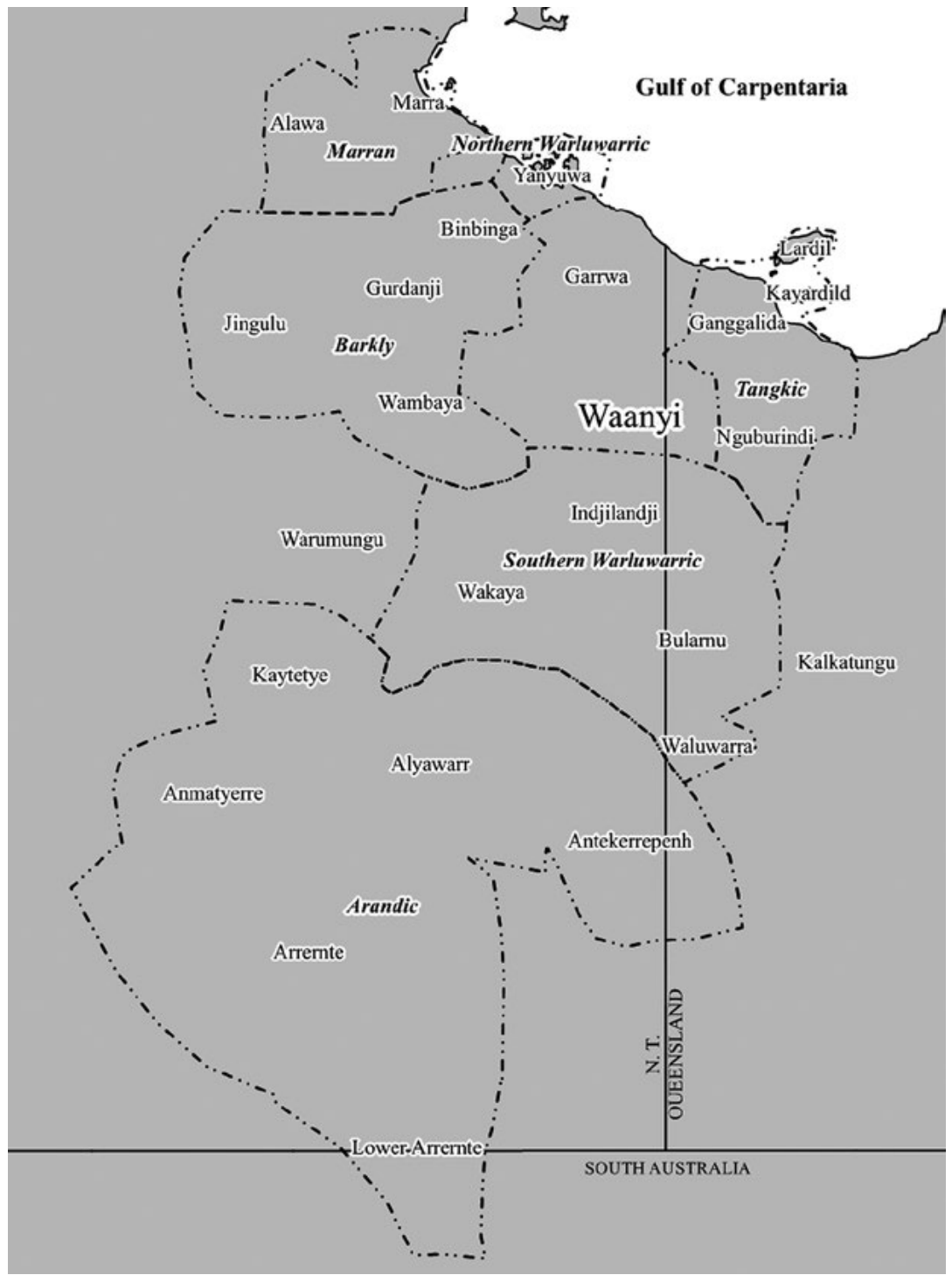

Figure 52: Location of Garrwan languages and their immediate neighbours.

Source: Editors' work.

As shown in Table 61, Waanyi mangkarri 'wife' is identical to the reconstructible Proto-southern Warluwarric term for 'wife', corresponding to Yanyula mangkayi 'woman's son's child' (ZSS/D), based on the data compiled by Breen $(2000 \mathrm{a}-\mathrm{d})$. Proto-southern Warluwarric *mangkarri has undergone well-documented sound changes in daughter languages, 
such as the loss of the nasal /ng/ in Bularnu and Warluwarra, with the compensatory tensing and devoicing of the following homorganic stop in Warluwarra (Breen 2004), in which this term is glossed as both 'sister-inlaw' and 'spouse', as opposed to ngutjana 'wife'. It is likely that Waanyi borrowed mangkarri from Warluwarric to distinguish 'wife' (ZSD) from 'husband' (FMB). ${ }^{39}$ There are gaps in the data on the southern Warluwarric languages because of the conditions under which these languages were recorded. In the northern language Yanyula, there is a clear pattern in both affinal and non-affinal terms in which the sex distinction is not lexicalised in the stems. However, sibling seniority is marked: -yalanji 'spouse of senior sibling' and -miyangki 'spouse of junior sibling..$^{40}$ While no Yinjirlanji 'wife' term has been recorded, the other southern languages formally distinguish 'wife' from 'husband' in the manner of the neighbouring Garrwan languages.

Table 61: Warluwarric kin terms.

\begin{tabular}{|c|c|c|c|c|c|}
\hline & \multirow{2}{*}{$\begin{array}{l}\text { Northern } \\
\text { Yanyula }^{1}\end{array}$} & \multicolumn{4}{|c|}{ Southern } \\
\hline & & $\begin{array}{l}\text { Yinji- } \\
\text { rlanji }\end{array}$ & Wakaya & Bularnu & Warluwarra \\
\hline \multicolumn{6}{|l|}{ Affinal } \\
\hline W(Z) & \multirow{2}{*}{$\begin{array}{l}\text {-wangu } \\
\text { kayikayi } \\
\text {-yalanji } \\
\text {-miyangki }\end{array}$} & & mengkarr & $\begin{array}{l}\text { magarri/ } \\
\text { magarradha }\end{array}$ & $\begin{array}{l}\text { makarri/ } \\
\text { ngutjana }\end{array}$ \\
\hline $\mathrm{H}$ & & yila & yili(nhath) & nganadha & dhawarra \\
\hline \multicolumn{6}{|c|}{ Non-affinal } \\
\hline $\mathrm{FM}(\mathrm{B} / \mathrm{Z})$ & ngabuji & $b a b i$ & \multirow{2}{*}{$\begin{array}{l}\text { jinkirdi (m) } \\
\text { bubabi (f) }\end{array}$} & \multirow[t]{2}{*}{ Yabara } & \multirow[t]{2}{*}{ bawa(ra) } \\
\hline ZSS/D & mangkayi & & & & \\
\hline MM & $\begin{array}{l}\text { kuku (m) } \\
\text { kukurdi (f) }\end{array}$ & yabi & $\begin{array}{l}\text { jinkirdi (m) } \\
\text { yiberi (f) }\end{array}$ & & \multirow[t]{2}{*}{ wapa } \\
\hline ZDS/D & wukuku & & $\begin{array}{l}\text { jinkirdi (m) } \\
\text { yiberi (f) } \\
\text { ngurrarl(tu) }\end{array}$ & gudhaninya ${ }^{2}$ & \\
\hline
\end{tabular}

Source: Author's work.

${ }^{1}$ While the Yanyula terms ngabuju and mangkayi mark the ascending/descending distinction in the harmonic generation, their Warlpiri cognates mark this same distinction but in the disharmonic generation. Ngapuju denotes the spousal relationship between F and M, or FZ and FFMB; whereas mangka. $n$ - denotes the spousal relationship between man's $D$ and his $\mathrm{MB}$, or woman's S and her DSD 'daughter-in-law'.

${ }^{2}$ Bularnu gudha in gudhaninya is possibly cognate with kuja in kujawuja.

39 In both Waanyi and Garrwa, there is other evidence of lexical borrowing of non-kin words including verbs that correspond with Proto-Warluwarric forms reconstructed by Breen (2004), such as verbs ending in -nja (e.g. karrinja 'stand', luwanja 'spin' and nanganja 'get').

40 Mushin (2012, p. 49) cited miyangi as WZ/HB in Garrwa; Heath (1981, p. 120) cited Marra -miyangkay stem for man's younger brother's wife and woman's husband's elder brother. 
Terms for 'husband' in Warluwarric languages vary. Like the Garrwan languages, three of the southern Warluwarric languages have a contrasting male and female spouse term, whereas the northern Warluwarric language Yanyula has a single 'spouse' stem, which is differentiated for male or female by the addition of gender-marking prefixes in the manner of some neighbouring non-Pama-Nyungan languages (Bradley 1992). ${ }^{41}$ It is possible that this (Warlpiri-like) pattern in which male spouse is not lexically distinguished from female spouse may have been the original Warluwarric pattern, with the distinct male (as opposed to female) spouse terms being an innovation in each of the southern Warluwarric languages with the adoption of the lexical pattern and perhaps vocabulary from a neighbouring language. If the Yanyula meaning of mangkayi as descending member of the FM class is original, then it is not surprising to see mangkarri 'wife' in southern languages, given that a wife is drawn from this 'descending' FM set, as shown in Figure 46. The 'spouse' term that may derive from Proto-Warluwarric, due to its presence in both northern and southern languages, is *yala - *yila, with reflexes -yala(nji), yila and yili.

The resemblance between the Waanyi descending MM set term ngurrali, shown in Figure 48 and discussed in the section 'Waanyi Kin Terms', and the Wakaya ngurrarl in Table 61 is obvious. ${ }^{42}$ Thus, Warluwarric languages appear to provide the source for at least two of the Waanyi terms under discussion: mangkarri (W) and ngurrali (ZDS/D).

It is not possible to reconstruct a Proto-Warluwarric FM term. The form * babi that McConvell (2008, p. 323) proposed as the Proto-PamaNyungan FM term is found in two members of the southern Warluwarric branch: Yinjirlanji and Wakaya. ${ }^{43}$ Given its widespread distribution in languages to the immediate east and south of the area under consideration, including in the Tangkic languages (to be discussed in the subsection 'Tangkic Languages'), its presence may be due to borrowing. In Wakaya, the only Warluwarric language for which distinct $\mathrm{FM}(\mathrm{Z})$ and FMB terms have been recorded, it is the term containing babi (bubabi) that designates the female member of the set. The northern Warluwarric language Yanyula has an FM term that matches the Waanyi male FMB form

41 Wakaya marks gender distinctions by suffixation.

42 Words ending in a lateral or rhotic consonant borrowed into Waanyi are typically augmented by final vowel $/ \mathrm{i} /$.

43 Following Carew (1993), Breen (2004, p. 226) grouped Yinjirlanji and Wakaya in the Ngarru branch of southern Ngarna (our Warluwarric), as opposed to Bularnu and Warluwarra. 
ngabuji-a term not found in other Warluwarric languages. In Yanyula, unlike Waanyi, this form does not encode the sex of referent. It is unlikely that Yanyula borrowed this word from Waanyi or vice versa, given that these languages are not immediate neighbours, being separated by Garrwa. Either language could have borrowed this word from another source, such as a Barkly language (to be discussed in the subsection 'Barkly Languages and Other Non-Pama-Nyungan Neighbours').

Interestingly, the MM term cannot be reconstructed in either southern or Proto-Warluwarric. There is only evidence of a distinct descending generation term in Wakaya. A southern Warluwarric term ${ }^{*} y b b r V$ may be the source of the Wakaya yiberi MM, as well as the Bularnu yabara FM, and may be related to Yinjirlanji yabi. The Warluwarra and Bularnu terms for the MM relationship appear to be distinct innovations, as are the Yanyula terms that are identical in form and meaning to the corresponding Waanyi terms (i.e. kuku MMB and kukurdi MM[Z]). Yanyula also has a distinctive, but related, descending generation term wukuku that follows a pattern of word formation that is quite common in north-west Queensland and southern Gulf languages, whereby the final CV of a kinterm is reduplicated to derive a related term, such as a grandchild term from a grandparent form or a special vocative or nominative form-for example, Kalkutungu FM papi > papipi, MM muju > mujuju, MF jaji > jajiji and FF ngaja > ngajaji (Blake 1979, pp. 81-2). Given that the ProtoWarluwarric word initial $/ \mathrm{k} /$, continued as such in southern languages, corresponds with /w/ in Yanyula (Brammall 1991; Carew 1993), it seems likely that this 'descending' form wukuku derives from an earlier * $k u k u k u$ form. The 'ascending' / $\mathrm{k} /$ initial forms kuku and kukurdi must be later innovations in Yanyula from a non-Warluwarric source. This source may be a Garrwan language, since one finds Garrwa kukuku glossed as a dyadic MM term: "MM and DS/D" (a maternal grandmother and her grandchild)' (Mushin 2012), in addition to kukudi and kukuli; however, other languages in contact with Yanyula are also possible sources. ${ }^{44}$

44 Other examples of this pattern of partial reduplication in Garrwan languages are G. bababa-nya 'younger B/Z' (cf. baba 'elder B/Z') and W. kabubu 'junior MB'. 


\section{Tangkic Languages}

The Tangkic languages spoken to the north and east of Waanyi (and Garrwa) also distinguish wife from husband, as shown in Table 62. Unlike the Warluwarric languages that are classified as Pama-Nyungan, the Tangkic languages are classified as non-Pama-Nyungan, although they have many Pama-Nyungan features (Evans 1995).

Although 'wife' in all three languages can be derived from a common Tangkic source, as shown in Table 62, 'husband' cannot, since the Lardil yukarr differs from the form common to the southern Tangkic Yukulta and Kayardild (Evans 1995, p. 12)..$^{45}$ The Tangkic ascending FM term *babi, whose reflexes in two southern Warluwarric languages were discussed in the section 'Comparison with Warluwarric Languages', differs from the descending (ZSS/D) terms. However, all three Tangkic languages show the same form-meaning pattern, apart from the lack of sex distinction in Lardil in the descending MM term manyin, akin to the Waanyi and Warlpiri pattern. Unlike Waanyi, but like Garrwa and Yanyula, all members of Ego's ascending FM group are referred to by a single term that does not distinguish male from female members. Again, unlike Waanyi, the distinction between ascending and descending generation FM kin is marked, without encoding a sex distinction. As mentioned in the previous section, two southern Warluwarric languages have reflexes of Tangkic * ${ }^{*} a b i$ as their FM form. ${ }^{46}$ This form differs from the Garrwan FM ngawiji, but is widespread in Pama-Nyungan languages, including those of the Kalkutungu (Blake 1979) and Maric groups (Alpher 2014) spoken to the south-east in Paman and Wik languages (Hale 1976a-c). ${ }^{47}$ The ascending MM term is also distinct from the descending MM terms in all three of these Tangkic languages, although the descending form in the southern languages is distinct from the northern Lardil form. As previously noted, while the southern languages distinguish the sex of the descending MM class members by unrelated forms, this distinction is not made in Lardil.

45 Tangkic *karndi may be cognate with Warlpiri karnta 'woman'; certainly, the Yukulta nominative form karndiya with the case-marking suffix -ya has been borrowed unanalysed into Warlpiri as 'wife's brother' or as a term designating either a girl or boyfriend.

46 The absence of babi as a grandparent/child term in either of the non-Pama-Nyungan MarraAlawa or Barkly languages closest to the Garrwan and Tangkic-speaking areas suggests the presence of a lexical boundary in this area, marked by the presence or absence of a reflex of *babi as the FM term, which does not align with the Pama-Nyungan/non-Pama-Nyungan boundary.

47 Hale (1976a, 1976b) seemed to have mistakenly reconstructed Paman *papi as MF, although the supporting language forms are glossed FM (Alpher, pers. comm. July 2014). 
Table 62: Tangkic affinal and harmonic FM and MM terms.

\begin{tabular}{|l|l|l|l|l|l|l|l|}
\hline \multicolumn{7}{|l|}{ AFFINAL } & \multicolumn{2}{l|}{ NON-AFFINAL } \\
\hline & H & W & FM & ZSS/D & MM & ZDS & ZDD \\
\hline Yukulta & dirrkurli & $\begin{array}{l}\text { karndi- } \\
\text { ya }\end{array}$ & babiju & ngarrmanda(thu) & ngarriju & malunginta & kirrkunku \\
\hline Kayardild & $\begin{array}{l}\text { dirrkuli; } \\
\text { dunda } \\
\text { H(B), } \\
\text { WB }\end{array}$ & $\begin{array}{l}\text { karndi } \\
\text { W(Z/B), } \\
\text { HZ }\end{array}$ & $\begin{array}{l}\text { babiju } \\
\text { karndi }\end{array}$ & -ngarrmanda & ngarriju & malunginta & kirrkunku \\
\hline Lardil & yukarr & kernde & babe & Nginngin & nyerre & manyin & \\
\hline Tangkic & & ${ }^{*}$ karndi & ${ }^{*}$ babi- & ${ }^{*}$ ngarr- & ${ }^{*}$ nyarri & \multicolumn{2}{|l}{} \\
\hline
\end{tabular}

Source: Author's work.

A comparison of the Tangkic forms with Waanyi forms in Table 62 reveals no formal resemblance between them, and hence there is no evidence of either common descent or borrowing of these kin terms between these language groups, despite other evidence of borrowing between Waanyi and Yukulta that goes beyond the scope of this study. However, the lexical patterns of these languages converge with respect to which semantic distinctions are formally marked.

The fact that southern Warluwarric* mangkarri and Tangkic * karndi- W(Z) also have reflexes as affinal terms in the geographically distant Warlpiri language suggests that they may descend from terms that did not specify gender but rather the junior or descending spousal relationship ZSS/D, as with Yanyula mangkayi, which would apply to wife and wife's siblings. The use of Kayardild karndi as a general FM set term also points to the fact that a potential wife is drawn from this set. The variation in 'husband' terms within both the southern Warluwarric and Tangkic languages suggests independent innovations of specific 'husband' terms-either by narrowing the meaning of an original 'spouse' term or the introduction of a male-referring term.

\section{Barkly Languages and Other Non-Pama-Nyungan Neighbours}

The Barkly languages form a group of non-Pama-Nyungan languages spoken to the immediate west and south of the Garrwan group (see Harvey 2008). These languages have a gender-marking system marked by suffixation on nouns, which serves to distinguish male and female members of a relational set. In Table 63, data from two of the 
better documented of these languages are presented. The Wambaya data are from Nordlinger (1998) and the Jingulu data from Pensalfini (2011). Wambaya was spoken in an area to the immediate west of Waanyi country, whereas Jingulu was spoken further west, separated from Wambaya by another Barkly language, Ngarnka.

Table 63: Spousal terms in two Barkly languages.

\begin{tabular}{|c|c|c|}
\hline & Wambaya & Jingulu \\
\hline \multicolumn{3}{|l|}{ Affinal } \\
\hline $\mathrm{H}$ & gari $(\mathrm{H}, \mathrm{ZH})$ & ngambiya \\
\hline W & $\begin{array}{l}\text { gari-nya (W, HZ) } \\
\text { munggujbili-nya }\end{array}$ & $\begin{array}{l}\text { ngambiyi-rni } \\
\text { kabi-rni } \\
\text { nayu-rni }\end{array}$ \\
\hline \multicolumn{3}{|c|}{ Non-Affinal } \\
\hline $\mathrm{FM}(\mathrm{B} / \mathrm{Z})$ & $\begin{array}{l}\text { ngabuji (m) } \\
\text { ngayiji-nya (f) }\end{array}$ & \multirow[t]{2}{*}{$\begin{array}{l}\text { ngabuja }(\mathrm{m}) \\
\text { ngabuji-rni (f) }\end{array}$} \\
\hline ZSS/D & $\begin{array}{l}\text { ngaji-mi-ji (m) } \\
\text { ngaji-mi-nya (f) }\end{array}$ & \\
\hline $\mathrm{MM}(\mathrm{B} / \mathrm{Z})$ & $\begin{array}{l}\text { gugu (m) } \\
\text { gugu-nya (f) } \\
\text { gugu-rda (f) }\end{array}$ & $\begin{array}{l}\text { kuka (m) } \\
\text { kuku-rni (f) }\end{array}$ \\
\hline ZDS/D & $\begin{array}{l}\text { gugu-mi-ji (m) } \\
\text { gugu-mi-nya (f) }\end{array}$ & $\begin{array}{l}\text { kaminjarra }(\mathrm{m}) \\
\text { kaminjirri-rni }(\mathrm{f}) \\
\text { ZDS/D \& BDS/D }\end{array}$ \\
\hline
\end{tabular}

Source: Author's work.

1 Based on Pensalfini (2011), the distinction between the ascending and descending MM relation in Jingulu is marked by distinct stems, as opposed to the FM relation in which this distinction is not lexicalised. However, the descending term applies to both the descending FM and MF relations.

As the data in Table 63 show, the stem of the female term is mostly, but not in all cases, the same as that of the male term. For example, in both languages, husband is formally distinguished from wife by means of gender suffixes on a common stem-gari in Wambaya and ngambiyV in Jingulu — which marks the affinal relationship between spouses and their siblings, such that Wambaya gari-nya denotes any female member in the scope of this relationship (e.g. W, WZ and HZ), while the unaffixed term denotes any male member (i.e. H, HB or ZH). As in Waanyi and Garrwa, these Barkly languages formally distinguish male from female spouse and their siblings, but they do so by means of gender marking rather than 
distinct stems. ${ }^{48}$ However, the presence in Jingulu of 'wife' terms kabi-rni and nayu-rni bearing the feminine -rni suffix without an attested use of their stem in a corresponding 'husband' term raises the possibility that these stems derive from historic 'spouse' or non-affinal FM terms. This seems especially likely in the case of nayu, which bears a close phonological resemblance to the Garrwan 'husband' term *nawilu (see Table 60).

Like Waanyi and Garrwa, these Barkly languages also distinguish the affinal 'spousal' terms from the non-affinal FM and ZSS/D terms that between them designate the superset (or subsection) of which a spouse is a member. While the more westerly Jingulu does not formally distinguish ascending from descending FM kin, Wambaya does by augmenting the stem by the suffix $-m i$ to which the gender suffix is attached. The Wambaya ascending FM terms not only distinguish male from female members by means of gender affixation, but also have distinct (if cognate) stems. The male form is identical to the Waanyi FMB and Yanyula $\mathrm{FMB} / \mathrm{Z}$ term ngabuji, while the $\mathrm{FM}(\mathrm{Z})$ stem ngayiji is almost identical to the Waanyi and Garrwa ngawiji. ${ }^{49}$ It is not possible to know at what stage this word entered Wambaya-it might have entered the language from Garrwan as ngawiji, undergoing just the change from $/ \mathrm{w} /$ to $/ \mathrm{y} /$. If we were to reconstruct the ultimate ancestor of this word, it would be in the form *ngabu-ju in a language in which the final syllable functioned as a suffix (see McConvell 2008 for a discussion of kin suffixes including $-j u$ - thu in Australian languages). The fact that the various cognate forms that occur in Garrwan and Barkly languages, as well as in Yanyula, have analysed the original suffix as part of the stem, suggests that these terms were borrowed into these languages—although, in two stages. We argued in the section 'Waanyi Kin Terms' that the lenited form (with medial /w/) in Garrwan languages must predate the entry of the non-lenited ngabuji form. However, in the case of Wambaya, it is more likely that the lenited form entered this language from a Garrwan language in order to mark the male/female distinction with distinct stems (in addition to the feminine suffix), given its absence from Jingulu. Unlike in the Garrwan languages, there is no evidence in Wambaya for historical lenition of intervocalic stops to glides.

48 The Warluwarric languages, Wakaya and Yanyula, also have formal gender systems including a masculine/feminine contrast.

49 The correspondence between Garrwan $w$ and Barkly $y$ is observed in both the spouse term (nawilu versus nayu) and the Wambaya $\mathrm{FM}(\mathrm{Z})$ term (ngawiji versus ngayiji). 
The other interesting difference between Wambaya and Jingulu is that the former encodes the ascending/descending contrast in the FM set with distinct stems in addition to a 'descending' suffix -mi-, while this distinction is unmarked in Jingulu. While the Wambaya affinal 'spousal' terms are unrelated formally to the FM-ZSS/D terms, the two sets of corresponding Jingulu terms may be related; however, showing this to be, or not be, the case takes us beyond the scope of this chapter.

Turning now to the Barkly MM-ZDS/D terms, we find the same stem as in the corresponding Garrwan and Yanyula terms-namely, $k u k u .{ }^{50}$ The distinction between male and female terms is marked by affixation, as is the ascending/descending contrast in Wambaya only. We recall that the distinction between male and female MM class members in both Waanyi and Yanyula is marked by a suffix-written -rdi in Yanyula and $-d i$ in Waanyi (whereby there is no contrast between alveolar and retroflex stops). However, this suffix is not active in either language. ${ }^{51}$ The female form $k u k u(r) d i$ has been borrowed into these languages as an unanalysed form contrasting with the root form kuku. Nordlinger (1998, p. 69) documented alternative feminine suffixes, -nya or $-r d a$, on three of the Wambaya grandparent terms, including FM and MM terms. ${ }^{52}$ We might speculate that both Waanyi and Yanyula incorporated their contrasting MM forms from a Barkly language closely related to Wambaya, in which the female affix was $-r d i$, rather than $-r d a .^{53}$

It is also possible that Yanyula borrowed the contrasting $k u k u$ and $k u k u(r) d i$ from a non-Pama-Nyungan source, given its absence from the southern Warluwarric languages. This said, the presence of wukuku in Yanyula (see Table 61), with the descending generation MM meaning, suggests pre-Yanyula ${ }^{*} k u k u \mathrm{MM}$, unless it can be shown that wukuku has been borrowed into Yanyula. An alternative source of the $-(r) d i$ suffix is from neighbouring Marra, which affixes $-r d i(\sim-r i)$ to certain kin stems,

50 The use of ' $\mathrm{g}$ ' in the Wambaya orthography does not indicate a different sound, since there is no voicing contrast in these languages; therefore, the Wambaya ' $g$ ' corresponds to Jingulu ' $k$ ' (also the symbol used in the writing conventions of the other languages under consideration).

51 The suffix -rdi is found on kin terms over a wide area without having a female or femininemarking function (McConvell 2008; Nash 1992). It seems to contrast with other sets of original kin suffixes such as $-j u /$-thu, seen on the Tangkic MM and FM terms in Table 62.

52 These variants were also recorded for the term for mother's sister.

53 Other Barkly languages such as Kurdanji and Binbinka were spoken in the area to the north of Wambaya, bordering on Yanyula and Garrwa countries. The documentation of these languages is too fragmentary to allow us to know if -rdi marked feminine in either of these languages. Nordlinger (1998, p. 68) noted that Wambaya -rdi is the non-absolutive suffix form on kin terms referring to males-for example, gari 'husband' (absolutive) and gari-rdi 'husband' (non-absolutive). 
including some harmonic terms to signal a first-person propositus reading (e.g. muri-rdi 'my $\mathrm{FF}(\mathrm{B}) / \mathrm{BSS}$ '), while the prefix $n$ - marks feminine gender. However, while gugu is the $\mathrm{MM}(\mathrm{B} / \mathrm{Z})$ stem in Marra vocative forms, alternating with kaka, Heath (1981, pp. 115-17) did not record it bearing the -rdi suffix in its first-person propositus form. Neither a Barkly language (on the basis of our limited data) nor a Marra origin accounts for the presence of kukurdi in Yanyula and Waanyi as the marked feminine term contrasting with kuku. Alawa and Marra affinal and non-affinal harmonic roots are listed in Table 64. ${ }^{54}$

Table 64: Marra and Alawa harmonic generation roots. ${ }^{55}$

\begin{tabular}{|c|c|c|c|c|c|c|}
\hline & \multicolumn{2}{|l|}{ AFFINAL } & \multicolumn{4}{|c|}{ NON-AFFINAL } \\
\hline & $\mathrm{H} / \mathrm{W}$ & WB/ZH & FM & MF & MM & FF \\
\hline Marra & mimay/maygurla & $\begin{array}{l}\text { wumbarna } \\
\text { (senior) } \\
\text { mimi (junior) }\end{array}$ & mimi & bija(ja) & $\begin{array}{l}\text { kuku/kaka } \\
\text { kangkurl } \\
\text { (ZDS/D) }\end{array}$ & muri \\
\hline Alawa & mimay & kaykay & \multicolumn{2}{|c|}{$\begin{array}{l}\text { jabjab, kardikardi } \\
\text { (FM/MF) }\end{array}$} & $\begin{array}{l}\text { kuku(ku) } \\
\text { wujarra } \\
\text { (ZDS/D) }\end{array}$ & $\begin{array}{l}\text { kangku } \\
\text { muri } \\
\text { (BSS/D) }\end{array}$ \\
\hline
\end{tabular}

Source: Author's work.

While Marra, like the Garrwan and other languages surveyed herein, distinguishes FM from MF, Alawa does not. However, mimi, which is both FM and WjB in Marra, denotes MF in Garrwan languages, whereby it also applies to FZS/D and MBS cross-cousins. The Marra distinction between mimi FM and bija MF may reflect an innovation from a system such as the Alawa one that does not mark this distinction. This innovation may have been motivated by a change in marriage patterns in which this distinction was salient. In a first cross-cousin marriage in which a mother-in-law and father-in-law are drawn from the sets containing ego's FZ and $\mathrm{MB}$ respectively, the spouse is from the set that contains both MF and FM, as in a four-section system, and equivalence between a 'spouse' and 'crosscousin' term is to be expected. However, the equivalence between the

$54 \mathrm{Kuku}$ as a MM term is not limited to non-PN languages; it is also attested in PN languages including those in the Maric group (see Breen 1973 for Bidyara-Gungubula descending generation examples: gugunyundila DD and gugundyila DS). It is also possible that the kuku root in Warlpiri kukurnu 'junior B' is cognate with kuku ' $\mathrm{MM} / \mathrm{DD} / \mathrm{S}$ ' in the languages discussed herein.

55 Both languages have additional terms that denote the kin classes in Table 63, which sets out a simplified list privileging terms cognate with those found in Garrwan languages. Heath's (1981, pp. 96-129) documentation of Marra kin terms and associated morphology showed considerable complexity with stems varying as a function of the value of the propositus suffix and the discourse use. For ease of comparison, I have transcribed 'g' in cited sources by ' $k$ '. 
Marra mimi FM and WB, as distinct from bija MF, reflects a second crosscousin marriage, as in the vocabulary of the other languages considered. ${ }^{56}$ Traces of a transition from one type of marriage to another is also seen in the use of mimay as the H/W term in both Marra and Alawa, whereas mimayi applies to a spouse's $\mathrm{MB}$, which includes a woman's son-in-law in Waanyi. The change in the system of wife bestowal can be modelled as the move from the direct bestowal of a man's daughter as spouse of his sister's son to an indirect exchange between cross-cousins of sister's daughters as mother-in-law, as previously discussed. Within such a marriage system, the role of $\mathrm{MM}(\mathrm{B})$ plays a crucial role, which motivates the linguistic expression of the socially relevant distinction between $\mathrm{MM}(\mathrm{B} / \mathrm{Z})$ and other grandparent relations and may account for the spread of a distinct MM term such as kuku, which has crossed a number of genetic linguistic boundaries in the Gulf area. The association of kangkulkangkurl with both MM and FF also points to a previous 'section-like' system in which these relational categories were subsumed into a single class. Mimayi is not the only term that denotes a harmonic generation relation in Alawa, but a disharmonic one in Garrwan. The Alawa MF/FM term kardikardi has the same form as the Garrwan ZS/D term written kadikadi ${ }^{57}$ Conversely, the disharmonic Alawa ngabuji HF has the same form as the harmonic Garrwan FM.

\section{Conclusions}

Explored herein are the possible motivations and sources for the rather irregular or anomalous pattern of marking of sex distinctions and generation levels in Waanyi harmonic ascending/descending kin terms. I have argued that these lexical contrasts are not random but reflect key social distinctions at the core of the system of affinal kin relationships and the way in which these affinal relationships intersect with the classificatory non-affinal kinship terminology. While the distinctions encoded in the kin terms discussed correspond to very salient distinctions in terms of traditional marriage alliances and wife-bestowal practices, a comparison with a more western Pama-Nyungan language, namely Warlpiri, shows

56 Marra bija MF may be cognate with the initial two syllables in Waanyi bujarra MBD 'cousinmother' (Trigger 1982, p. 24), as well as F/MjZ (Seccin corpus) contrasting with mimi FZS/D and maka(ngu) MBS/D. Mushin (2012, p. 48) recorded bujarra as MFZ, MjZ and FjBW.

57 Heath (1981, p. 117) recorded disharmonic gardigardi 'mother's senior sister' alternating with stem -jamul. 
that the Waanyi lexical pattern that formally distinguished the sex of members of the FM and MM classes cannot be solely attributed to these features of social organisation. However, the existence of a marked term for descending members of the MM class in both Waanyi (ngurrali) and Warlpiri (mirntirdi) would indicate that this distinction is in fact more salient than the sex distinction. This generational distinction in MM class terms is also found in other Gulf languages, including the Tangkic, (some) Warluwarric and Barkly languages, as well as in Marra and Alawa.

The question was then raised as to whether the existence, in Waanyi, of spousal terms that distinguish both generation level and sex might not trigger, or at least reinforce, the marking of sex distinctions in FM nonaffinal terms - that is, ngabuji male member of FM class and ngawiji female member of FM class. Recall nawi 'husband' = male member of FM class in upper harmonic generation to spouse, while mangkarri 'wife' = female member of FM class in lower harmonic generation to spouse. In comparing Waanyi and Garrwa, we also noted the distinct ways in which generation level is marked in these languages. While in Waanyi, the lexical marking of the ascending/descending contrast in harmonic generation terms is limited to the MM class (abstracting away from the use of murimuri as a more general descending generation term), Garrwa employs the suffix -nya to mark descending generation terms, as part of a more general distinction between senior and junior members of a related pair. There is also evidence that this suffix also operated in Waanyi.

Casting the net more widely, it was found that languages of four distinct groups-Garrwan, Warluwarric, Tangkic and Barkly_share a lexical pattern that involves a formal distinction between affinal spousal terms and non-affinal FM terms, as well as a distinction between male and female spousal terms. However, the marking of a male/female distinction in nonaffinal terms is less common in those languages lacking formal gendermarking affixation. In Tangkic languages, while the ascending/descending contrast is marked in both FM and MM classes, the sex distinction is marked on the descending MM terms only in the southern Tangkic languages Kayardild and Yukulta that are spoken in close proximity to the Garrwan languages (see Table 62).

What is quite striking in comparing Tangkic and Garrwan non-affinal terms is the lack of cognate terms for the relationships under discussion, despite their geographical adjacency. However, at least two Garrwan affinal terms are cognate with Tangkic ones: Waanyi senior brother-in- 
law term nabinabi ' $\mathrm{ZH}$ ' is identical to the Yukulta junior brother-in-law WB term (and the Yanyula ZB term); and Waanyi affinal 'father-inlaw' term kadu-nganja equates with the Tangkic *kardu ZS/D as a nonaffinal term, and as 'father-in-law' when used as an affinal term. Recall that a father-in-law is drawn from the superset containing one's sister's children. A comparison of Warluwarric and Garrwan terms indicates a greater number of Warluwarric terms shared with Waanyi than with Garrwa. These Waanyi terms of probable Warluwarric origin reinforced, if they did not initiate, the expression of the sex distinction in the spousal terms - mangkarri 'wife' contrasting with the inherited Garrwan spousal term nawil $u$ 'husband'. Borrowing allowed the marking of the ascending/ descending contrast in the MM set: kuku/kukudi versus ngurrali (< Wakaya ngurrarl) in the Seccin corpus. It was also noticed that FM terms in two southern Warluwarric languages appear to be cognate with the Tangkic term *babi-further indications of possible contact induced borrowing between members of these language groups. Conversely, the shared Barkly and Garrwan FM and MM terms are quite distinct from either the Tangkic or southern Warluwarric ones. The Yanyula FM and MM terms, which are quite distinct from those in the southern Warluwarric languages, possibly resulted from borrowing from their non-Pama-Nyungan neighbours, following the separation of the northern and southern Warluwarric languages. However, the presence of the descending MM term $w u k u k u$ with a lenited initial consonant suggests the possibility that a pre-Yanyula MM term * $k u k u$ was shared with the Barkly, Garrwan and other non-Pama-Nyungan languages. This scenario raises the possibility that the southern Warluwarric languages replaced $k u k u$ with terms that were borrowed from other languages or through extending the meaning of items from their own lexicons, which would account for the diversity of MM terms in these languages. A similar scenario might also explain the distribution of FM terms in southern Warluwarric languages, which distinguishes Yinjirlanji and Wakaya from Bularnu and Warluwarra.

The Barkly languages are typologically quite distinct from the Garrwan and Tangkic languages in terms of having a highly transparent and morphologically active system of gender marking. Thus, contrasting masculine and feminine kin word forms with shared roots is used to express the sex distinction, as seen most clearly in the Jingulu data (Table 63). This contrasts with the use of distinct male- and femalereferring lexical roots in the other languages. However, Wambaya, spoken in the immediate vicinity of Waanyi, marks the sex contrast for FM 
ascending kin by distinct lexical roots that are almost identical with the Waanyi forms, as well as the addition of the feminine suffix to the femalereferring stem. Like the Tangkic languages (Table 62), Wambaya, but not Jingulu, also marks the ascending/descending FM generation contrast with distinct stems, as well as with a special descending generation suffix $-m i$ to which the gender suffix is attached. However, Jingulu does not mark the generational contrast. Recall that western Garrwa, and some dialects of Waanyi, also mark the descending generation with a suffix -nya.

The pattern that emerges is the marking of both sex and generation level distinctions in FM and MM class terms as a shared feature of the languages of the southern Gulf of Carpentaria region; further, more lexically marked distinctions are made towards the eastern end of this region, especially in the southern Tangkic languages. Waanyi has borrowed terms from neighbouring southern Warluwarric languages in order to encode distinctions that were probably not made in ProtoGarrwan. These include mangkarri 'W(Z)' and ngurrali 'ZDS/D', as well as incorporating, along with Yanyula, a female MM form kukudi, possibly derived from a neighbouring non-Pama-Nyungan language, as opposed to the unmarked kuku MMB. Although Barkly languages formally distinguish all male from female kin because of their gender-marking system, it is all the more notable that the marking of the sex contrast is confined in Waanyi to the MM and FM classes and not to the other 'grandparent' classes, despite the similarity of stem forms for the FF form kangku across Barkly, Garrwan and Tangkic languages. ${ }^{58}$

It is also notable that Waanyi and Garrwa share their FM and MM terms with the Barkly languages and Yanyula, rather than with southern Warluwarric or Tangkic languages. While Tangkic and some southern Warluwarric appear to share cognates of the FM term $<{ }^{*} b a b i$, there are no shared grandparent terms between Garrwan and Tangkic languages, despite the fact that these languages share a border on the eastern side of the Garrwan group. This suggests that the Garrwan-speaking peoples may have origins originally extending to the south and west of the area they occupied at European contact, rather than to the north-east of this area.

58 The Garrwan MF term mimi is shared with the Warluwarric languages, but not with the Barkly or Tangkic languages. However, it is found in Marra as both a non-affinal FM term (Heath 1981, pp. 118-19) and the affinal brother-in-law term. 
Finally, the 'anomalies' in the Waanyi terms for ascending and descending harmonic generation terms reflect a shared system of marriage alliance and wife bestowal in a context of social and linguistic interaction between the peoples of the southern Gulf of Carpentaria region, leading to the 'adjustments' in kin terminologies seen in the Waanyi examples discussed. This contact was marked by multilingualism, as well as shared ceremonies and wife exchange across language groups. A more extensive comparison of kin terminologies across these languages, and a closer study of linguistic changes, both semantic and phonological, within groups, might permit the establishment of a relative time line to the borrowing and a surer evidenced directionality of the borrowing that has taken place since these language groups have been in such close contact. ${ }^{59} \mathrm{~A}$ brief comparison with the lexicalisation pattern in affinal and non-affinal harmonic generation terms in the Marra and Alawa languages that are not spoken in immediate contact with the Garrwan-speaking area has led to the speculation that the lexical anomalies found in Waanyi and neighbouring languages reflect the change from a first cross-cousin marriage to a second cross-cousin marriage system involving mother-in-law exchange, in which the FM and MF classes have distinct roles. In FM and MM classes, Ego's parents' maternal parents have the complementary roles of wife receiver (FM) and wife bestower (MM), while within the MM class the distinction between wife bestower (MM[B]) and bestowed (ZDD) is also lexically marked.

\section{References}

Alpher, B 2014, Proto-Pama-Nyungan etyma list, Microsoft Word document file, accessed 6 August 2014.

Blake, B 1979, A Kalkatungu grammar, Pacific Linguistics B-5, Canberra: The Australian National University.

Blake, B 1988, 'Redefining Pama-Nyungan: towards the prehistory of Australian languages', in N Evans \& S Johnson (eds), Aboriginal Linguistics I, Armidale, NSW: University of New England, pp. 1-90.

59 Another aspect of the kin terminologies within these languages is the lexical marking of the senior/junior sibling relationship not only in the set of Ego's siblings, which is almost universal in Australian languages, but also in Ego's F and M sets. Again, this seems to be a phenomenon with its origins in the east, so that marking these distinctions in Garrwan languages has also involved borrowing kin terms from neighbouring languages, including Warluwarric. 
Blake, B 1990, 'Languages of the Queensland/Northern territory border: updating the classification', in P Austin, RMW Dixon, T Dutton \& I White (eds), Language and history: essays in honour of Luise A. Hercus, Pacific Linguistics C-116, Canberra: The Australian National University, pp. 49-66.

Bradley, J 1992, Yanyuwa wuka: language from Yanyuwa country. Ms 240p, St Lucia, Qld: The University of Queensland.

Brammall, D 1991, A comparative grammar of Warluwaric, BA (honours) thesis in linguistics, The Australian National University.

Breen, GJ n.d., Unpublished Waanyi field notes shared with Laughren.

Breen, GJ 1973, Bidyara and Gungabula: grammar and vocabulary, Linguistic communications 8, Melbourne: Monash University.

Breen, GJ 2000a, Grammar and dictionary of Bularnu, Alice Springs, NT: Ms. Institute for Aboriginal development.

Breen, GJ 2000b, Grammar and dictionary of Warluwarra, Alice Springs, NT: Ms. Institute for Aboriginal development.

Breen, GJ 2000c, Grammar and dictionary of Wakaya, Alice Springs, NT: Ms. Institute for Aboriginal development.

Breen, GJ 2000d, Injilanji vocabulary and grammar notes, Alice Springs, NT: Ms. Institute for Aboriginal development.

Breen, GJ 2003, 'Wanyi and Garrwa comparative data', in N Evans (ed.), The non-Pama-Nyungan languages of northern Australia: comparative studies of the continent's most linguistically complex region, Pacific linguistics 552 / Studies in language change, Canberra: The Australian National University, pp. 425-62.

Breen, GJ 2004, 'Evolution of the verb conjugations in the Ngarna languages', in C Bowern \& H Koch (eds), Australian languages: classification and the comparative method, Amsterdam: John Benjamins, pp. 223-240. doi.org/10.1075/cilt.249.14bre.

Carew, M 1993, Proto-Warluwarric phonology, BA (honours) thesis in linguistics, University of Melbourne. 
Dymock, J 1993, 'Something deep and rich: Indigenous and post contact environment and heritage materials relevant to the Lawn Hill/ Riversleigh district of Queensland', Report prepared for Department of Environment and Heritage Queensland, August 1993.

Evans, N 1995, A grammar of Kayardild, New York: Mouton de Gruyter. doi.org/10.1515/9783110873733.

Evans, N 2003, 'Introduction: comparative non-Pama-Nyungan and Australian historical linguistics', in $\mathrm{N}$ Evans (ed.), The non-PamaNyungan languages of northern Australia: comparative studies of the continent's most linguistically complex region, Pacific linguistics 552 I Studies in language change, Canberra: The Australian National University, pp. 3-25.

Flint, E 1964, Audio recordings of Waanyi language made at Doomadgee Qld as part of the Queensland Speech Survey of Aboriginal English. Canberra: Australian Institute of Aboriginal and Torres Strait Islander Studies (Audio collection: QSS_01, Accession No. 005928-006071).

Hale, K 1976a, 'Phonological developments in particular northern Paman languages', in P Sutton (ed.), Languages of Cape York, Canberra: Australian Institute of Aboriginal Studies, pp. 7-40.

Hale, K 1976b, 'Phonological developments in a northern Paman language: Uradhi, in P Sutton (ed.), Languages of Cape York, Canberra: Australian Institute of Aboriginal Studies, pp. 41-9.

Hale, K 1976c, 'Wik reflections of Middle Paman phonology', in P Sutton (ed.), Languages of Cape York, Canberra: Australian Institute of Aboriginal Studies, pp. 50-60.

Harvey, M 2008, Proto Mirndi: a discontinuous language family in northern Australia, Pacific linguistics 593, Canberra: The Australian National University.

Harvey, M 2009, 'The genetic status of Garrwan', Australian Journal of Linguistics, 29(2), pp. 195-244. doi.org/10.1080/ 07268600902823102.

Heath, J 1981, Basic materials in Mara: grammar, texts and dictionary, Pacific linguistics C-60, Canberra: The Australian National University. 
Keen, S 1983, 'Yukulta', in RMW Dixon \& BJ Blake (eds), Handbook of Australian languages, vol. 3, Canberra: The Australian National University, pp. 191-226.

Laughren, M 1982, 'Warlpiri kinship structure', in J Heath, F Merlan \& A Rumsey (eds), Languages of kinship in Aboriginal Australia, Oceania linguistic monographs no. 24, Sydney: University of Sydney, pp. $72-85$.

Laughren, M 2001, 'What Warlpiri “avoidance” registers do with grammar', in J Simpson, D Nash, M Laughren, P Austin \& B Alpher (eds), Forty years on: Ken Hale and Australian languages, Pacific linguistics 512, Canberra: The Australian National University, pp. 199-225.

McConvell, P 2008, 'Grand-daddy morphs: the importance of suffixes in reconstructing Pama-Nyungan kinship', in C Bowern, B Evans \& L Miceli (eds), Morphology and language history: in honour of Harold Koch, Current issues in linguistic theory 298, Amsterdam/Philadelphia: John Benjamins, pp. 313-27. doi.org/10.1075/cilt.298.27mcc.

McConvell, P \& Laughren, M 2004, 'The Ngumpin-Yapa subgroup', in C Bowern \& H Koch (eds), Australian languages: classification and the comparative method, Amsterdam: John Benjamins, pp. 151-77. doi.org/10.1075/cilt.249.11mcc.

Mushin, I 2012, A grammar of (western) Garrwa, Pacific linguistics 637, Berlin: Walter de Gruyter Mouton. doi.org/10.1515/9781614512417.

Nancarrow, C et al. (comp.) 2014, Ganggalida dictionary and thesaurus: a vocabulary of the Yugulda language of the Ganggalida people, northwest Queensland, Cairns, Qld: Gangalidda and Garawa Native Title Aboriginal Corporation, c/o the Carpentaria Land Council.

Nash, D 1992, 'An Australian kinship affix * ${ }^{*} r t i$, in N Evans \& C Goddard (eds), Memorial volume for Steve Johnson, Australian Journal of Linguistics, 12(1), pp. 123-44. doi.org/10.1080/07268609208599473.

Nordlinger, R 1998, A grammar of Wambaya, Northern Territory (Australia), Pacific linguistics C-140, Canberra: The Australian National University. 
O'Grady, G 1979, 'Preliminaries to a proto Nuclear Pama-Nyungan stem list', in SA Wurm (ed.), Australian linguistic studies, Pacific Linguistics Series C-54, Canberra: The Australian National University, pp. 107-39.

O'Grady, G, Voegelin, C \& Voegelin, F 1966, 'Languages of the world: Indo-Pacific fascicle six', Anthropological Linguistics, 8(2), pp. 1-197.

Osborne, C 1966, A tentative description of the Wanyi language. Ms. 58p, Canberra: Australian Institute of Aboriginal and Torres Strait Islander Studies (Manuscript collection: PMS1360).

Pensalfini, R 2011, Jingulu texts and dictionary, Pacific linguistics 536, Canberra: The Australian National University.

Scheffler, H 1978, Australian kin classification, Cambridge: Cambridge University Press. doi.org/10.1017/CBO9780511557590.

Sharpe, M 1967, Language elicitation and discussion from Woorabinda, Qld, Canberra: Australian Institute of Aboriginal and Torres Strait Islander Studies (Audio collection: SHARPE_M10 - 01062).

Sharpe, M 2001, Alawa nanggaya nindanya yalanu rugalarra: Alawa-KriolEnglish dictionary (longer edition), Adelaide: Caitlin Press.

Tindale, N 1974, Aboriginal tribes of Australia, Berkeley/Los Angeles: University of California Press, and Canberra: The Australian National University Press.

Trigger, D 1982, Nicholson River (Waanyi-Garrawa) land claim, Darwin: Northern Land Council (map prepared by J Dymock and D Trigger), p. 134. 


\section{Appendix 1: Waanyi Non-Affinal Kin Terms Cited in This Chapter}

\begin{tabular}{|c|c|c|c|c|c|c|c|c|c|}
\hline \multicolumn{2}{|c|}{$\begin{array}{l}\text { Ascending } \\
\text { harmonic }\end{array}$} & \multicolumn{2}{|c|}{$\begin{array}{l}\text { Descending } \\
\text { harmonic }\end{array}$} & \multicolumn{2}{|c|}{$\begin{array}{l}\text { Ascending } \\
\text { disharmonic }\end{array}$} & \multicolumn{2}{|c|}{$\begin{array}{l}\text { Descending } \\
\text { disharmonic }\end{array}$} & \multicolumn{2}{|c|}{ Same generation } \\
\hline $\mathrm{FF}(\mathrm{B} / \mathrm{Z})$ & kangku & BSS/D & $\begin{array}{l}\text { kangku, } \\
\text { murimuri }\end{array}$ & $F$ & murriba & $B S / D$ & jawaji & sB & bawa \\
\hline $\mathrm{FM}(\mathrm{Z})$ & ngawiji & ZSD & ngawiji & $\mathrm{FZ}$ & kawija & & & sz & balala/maju \\
\hline FMB & ngabuji & ZSS & ngabuji & MB & $\begin{array}{l}\text { kadidi, } \\
\text { kabubu }\end{array}$ & ZS/D & jabulu & $j B / Z$ & $\begin{array}{l}\text { dawirri/ } \\
\text { kakulu }\end{array}$ \\
\hline $\mathrm{MF}(\mathrm{B} / \mathrm{Z})$ & mimi & FZS/D & $\begin{array}{l}\text { mimi, } \\
\text { murimuri }\end{array}$ & $M$ & ngada & & & MBS/D & $\begin{array}{l}\text { mimi, } \\
\text { maku(ngu) }\end{array}$ \\
\hline $\mathrm{MM}(\mathrm{Z})$ & kukudi & ZDS/D & ngurrali; & MMBS & mimayi & ZDSS & mimayi & FZS/D & $\operatorname{mimi}$ \\
\hline MMB & kuku & & & MMBD & ngunyarri & ZDSD & ngunyarri & & \\
\hline
\end{tabular}

\section{Appendix 2: Waanyi Affinal Kin Terms}

\begin{tabular}{|l|l|l|l|}
\hline \multicolumn{2}{|l|}{ Harmonic } & Disharmonic \\
\hline H(sB) & nawi & HFMF & kadu-nganja \\
\hline W(Z) & mangkarri & MMBD; MBDD; H/WM & ngunyarri \\
\hline Man's ZH & nabinabi & MMBS; MBDS; ZDH & mimayi \\
\hline WB; HjB & kayikayi & DH & ngakinburrunyi \\
\hline
\end{tabular}


This text is taken from Skin, Kin and Clan: The dynamics of social categories in Indigenous Australia, edited by Patrick McConvell, Piers Kelly and Sébastien Lacrampe, published 2018 by ANU Press, The Australian National University, Canberra, Australia.

doi.org/10.22459/SKC.04.2018.12 